\title{
Influence of Japonisme on Art of M. K. Čiurlionis and His Contemporaries
}

\begin{abstract}
The aim of this paper is to show how Japonisme was introduced to Europe in the late $19^{\text {th }}$ century and how it influenced artists in major cities. Japanese woodblock prints (ukiyo-e), especially those of Hokusai and Hiroshige, fascinated the Impressionists and other contemporaries such as Claude Monet (1840-1926), Vincent van Gogh (1853-1890), and James Abbott McNeill Whistler (1834-1903). Many of them adopted japonaiserie motifs in their paintings or sculptures, and it formed a major artistic trend called Japonisme. The Lithuanian composer and painter Mikalojus Konstantinas Čiurlionis (1875-1911) was also influenced by the trend of Japonisme, especially from the paintings of the Impressionists or through artists in Poland. In Poland and Russia, Japanese artworks were imported by artists who had studied abroad, or by wealthy bourgeoisie such as Feliks "Manggha" Jasieński (1861-1929), a Polish collector whose nickname was directly associated with Japonisme, and Sergey Kitaev (1864-1927), an ardent Russian collector of Japanese artworks. In this article, Japonisme in European art in general will be outlined, together with similar tendencies in Čiurlionis' paintings, and then, examples of Japonisme-influenced paintings in Poland and Russia will be briefly shown. Finally, by focusing on Čiurlionis' paintings, it will be shown how he adopted Japonisme in three stages. In the first stage japonaiserie motifs were only partially borrowed. In the second stage ukiyo-e's motifs and pictorial schemes were applied to his paintings, and finally, in the third stage of borrowing, expressions of Japanese motifs in his most sublime style will be shown.
\end{abstract}

Keywords: Čiurlionis, Hokusai, Hiroshige, Japonisme, japonaiserie, ukiyo-e.

\section{Introduction}

Mikalojus Konstantinas Čiurlionis (1875-1911) was an outstanding Lithuanian, equally talented as a composer and a painter. In his time European arts were facing a major turning point and artists were eager to assimilate far-off foreign cultures in order to break down the wall of conservative traditionalism. The trend of Japonisme was one of the most distinctive features which dominated all of Europe from the second half of the $19^{\text {th }}$ century to the beginning of the 
$20^{\text {th }}$ century. Wealthy bourgeoisie had started collecting Japanese handiworks such as ceramics, fans, folding screens (byōbu), robes (kimono), and especially, colourful woodblock prints (ukiyo-e). Some artists adopted in their own works not only Japanese motifs but also unusual modes of representation. Čiurlionis may also have been influenced by Japanese art when he studied and stayed in Poland, Germany and Russia.

The influence of Japanese art on Čiurlionis' paintings was firstly argued by a Japanese researcher Ichiro Kato (1930-2003) in 1976. In his article, he pointed out that Čiurlionis' Finale from "Sonata No. 5 (Sonata of the Sea)" (1908, Fig. 1-1) has similarities to Katsushika Hokusai’s (1760-1849), The Great Wave off Kanagawa from "Thirty-Six Views of Mount Fuji" (ca. 1831-33, Fig. 1-2) and he presumed that it would be direct influence from the famous Japanese ukiyo-e. This theory have been received favourably and accepted generally as an established theory to the present. However, Kato did not consider how Čiurlionis came to know Hokusai's work. In the article, he also mentioned about similarity of colours between Čiurlionis' paintings and Japanese Buddhist pictorial art Mandala, and even invoked a Japanese aesthetic sense of Wabi-sabi irrelevantly. These comparisons are interesting enough however, there are only superficial resemblances and he did not clarify when and how Čiurlionis discovered Japanese art in factual contexts.

In Japan, art historians had researched on Japonisme from 1970s downward and showed many remarkable achievements. However, the research by Kato was almost unrecognised in Japan because he did not have any connection with an academic society in Japan. Even though an excellent exhibition of Čiurlionis' paintings was held in Tokyo in $1992^{1}$, none of Japonisme specialists in Japan tried to consider about the influence of Japonisme on Ciurlionis since then.

On the other hand, scholars of Čiurlionis' studies in Lithuania were stimulated by Kato's discovery and has started to consider about the influence of Japanese or Oriental art on Čiurlionis' art. Researches by Antanas Andrijauskas (2003, 2011 and 2013) and Rasa Andriušytė-Žukienè (2004) were the major achievements. Especially, insightful theory have been proposed by Andrijauskas (2011 and 2013) in which he discussed the possibility of the influence from Chinese and Japanese ink wash paintings (suibokuga) on Čiurlionis. As examples he pointed out some common features between them, mentioning Shübun's folding screen (byöbu) in the $15^{\text {th }}$ century, Landscape of the four seasons (Fig. 1-3), and Čiurlionis' Allegro from "Sonata No. 4 (Sonata of the Summer)" (1908, Fig. 1-4) and Summer II (1907, Fig. 1-5). However, these similarities seem not fully persuasive lacking substantive historical evidence. Similar to Kato's case, Andrijauskas' theory still remains hypothetical and requires more thoughtful consideration to prove how Čiurlionis could have known about such an old medieval Japanese suibokuga.

We instinctively feel some sort of similarities between Čiurlionis' quasi- 
monochrome paintings such as Allegro from "Sonata No. 2 (Sonata of Spring)" (1907, Fig. 1-6) and Chinese/ Japanese landscape paintings of suibokuga, however, there is no affirmative evidence which proves direct or indirect influence from Oriental art. Therefore in this paper, the possible influence from Japanese ukiyo-e on Čiurlionis' paintings will be considered only with materials which Čiurlionis actually had opportunities to see in all probability.

\section{Japonisme in Europe}

\section{and its influence on Čiurlionis and artists in Poland and Russia}

The most famous and well-appreciated ukiyo-e in Europe must have been Katsushika Hokusai (1760-1849)'s The Great Wave off Kanagawa from the series of "Thirty-Six Views of Mount Fuji" (ca. 1831-33, Fig. 1-2). Because of its unforgettable uniqueness, Hokusai's masterpiece influenced many French artists including Georges Lacombe (1868-1916)'s Blue Seascape, Effect of Wave (ca. 1893, Fig. 2-1), Henri-Gustave Jossot (1866-1951)'s The Wave (1891, Fig. 2-2) and Camille Claudel (1864-1943)'s The Wave or The Bathers (ca. 1893-1903, Fig. 2-3). Hokusai was praised as "one of the most outstanding artist in human history" by Louis Gonse (1841-1926), French art historian and chief editor of the Gazette des Beaux-Arts, in his own journal in 1883. Hokusai's oeuvre was thoroughly described in several books such as Hokusai (1896) by Edmond de Goncourt (1822-1896), and Etude sur Hoksaï (1896) by Michel Revon (18671947). It is a well-known fact that an English painter and illustrator Walter Crane (1845-1915) "introduced new levels of artistic sophistication to the art of illustration: after c. 1870 his designs show the influence of Japanese prints in the use of flat areas of colour and simple, often asymmetrical compositions, and of classical sculpture in the figures and draperies"2. The influence of Hokusai's Great Wave could be obviously seen in Crane's famous painting, Neptune's Horses (1892, Fig. 2-4). Čiurlionis adopted the similar "Great Wave" motive in his painting Finale from "Sonata No. 5 (Sonata of the Sea)" (1908, Fig. 1-1). Incidentally, the similar motive of "Great Wave" could be seen in Russian Ivan Bilibin (1876-1942)'s illustration for the picture book, The Tale of Tsar Saltan by Aleksandr Pushkin (1905, Fig. 2-5), published three years before Ciurlionis' painting. It clearly shows that Hokusai's masterpiece had been well known among the artists of Mir Iskusstva in St. Petersburg.

Even though Japanese ceramics were imported and appreciated as a part of chinoiserie in the time of Louis XIV of France, the major influence of Japanese art was only possible after the end of the Sakoku policy which strictly limited foreign exchanges in Japan from the $17^{\text {th }}$ to the middle of the $19^{\text {th }}$ century. The first major opportunities to introduce Japanese arts in Europe were the International Exhibition in London (1862) and the Exposition Universelle in Paris (1867). Simultaneously, several merchants in Paris and 
London actively imported Japanese artworks including ukiyo-e. From 1870s onward, Japanese art fascinated European artists such as Whistler, Beardsley, Manet, Degas, Monet, Van Gogh, Gauguin, and Klimt. They unanimously valued Japanese ukiyo-e highly, not only because of its exotic motifs but also because of its unusual modes of artistic representation. One important source of inspiration for those artists was an art magazine Le Japon Artistique edited by Siegfried Bing (1838-1905) published in 36 volumes in total in 1888-91. The magazine consisted of articles on Japanese arts written by specialists with illustrations of ukiyo-e, ink paintings, ceramics and many other handiworks from the Edo period.

Around the same time, CCiurlionis encountered two epoch-making exhibitions of Japanese arts held in Warsaw in the end of his stay in the city. The first exhibition was of Japanese ukiyo-e printings held in J. Kriwult's salon in 1900-01 and the second was at the beginning of 1901, of the exhibition of Feliks Jasieński's famous collection of Japanese arts. ${ }^{3}$ (Alber 1990, pp.1417). Furthermore, during the trip to Prague, Dresden, Nuremberg, Munich and Vienna in 1906 and the stay in St. Petersburg in his later years, he might have possibly encountered Japanese art in the these cities.

In fact, Čiurlionis' paintings contain complex mixtures of influences from various cultures and times. It is not an easy task to point out clear signs of the inspirations from ukiyo-e or adoptions of Japanese motifs in each individual work. The paintings described below are just the hypothetical examples that Čiurlionis seemed to have referred some compositional and representational ideas from ukiyo-e.

First, here is Claude Monet (1840-1926)'s Poplars in the Sun (1891, Fig. 3-1). The two-dimensional arrangement of a line of trees, through which the distant view is partly seen, has been unanimously regarded as the influence from Hokusai's, Hodogaya on the Tōkaidō from "Thirty-Six Views of Mount Fuji" (ca. 1830-32, Fig. 3-2). Similar examples are easily found among Impressionist and Post-Impressionist landscape paintings (Mabuchi 1997, p.131). In Čiurlionis' Summer I from the triptych (1907, Fig. 3-3) we can recognise the analogous composition of trees. Is it possible to regard it as influenced by ukiyo-e? As mentioned above, Čiurlionis surely saw the exhibitions of ukiyo-e in Warsaw about 1900. Japonisme was a trend among young Polish artists and they attempted to adopt innovative techniques learned from ukiyo-e. The compositional scheme which shows distant views through trees was also tried by Čiurlionis' contemporary Polish painters such as Jan Stanisławski (18601907)'s Poplars on the Water (1900, Fig. 3-4), Stanisław Kamocki (18751944)'s View over the Monastery at Czerna (1908, Fig. 3-5), and Ferdynand Ruszczyc (1870-1936)'s Winter Tale (1904, Fig. 3-6). It is natural to deduce that Čiurlionis also adopted the same setting à la japonaise, inspired directly by ukiyo-e or indirectly through the examples of Polish artists. The aesthetics of Japonisme are admitted in the paintings by contemporary Russian Igor 
Grabar (1871-1960). In his The Frost (1905, Fig. 3-7) and Winter Morning (1907, Fig. 3-8), the two-dimensional arrangement of a line of trees, through which the distant view is partly seen, has been unanimously regarded as the influence from Japonisme.

Next, here is Vincent van Gogh (1853-1890)'s Japonaiserie: Bridge in the Rain (after Hiroshige) (1887, Fig. 4-1). He became interested in Japanese ukiyo-e in 1885 when he still lived in Arnhem. In Antwerp he decorated the walls of his studio with ukiyo-e prints. After he moved to Paris at the end of February in 1886, he often visited the famous antique shop of Siegfried Bing (1839-1905) on the rue de Province and collected hundreds of ukiyo-e together with his brother Theo. At that time he made three copies of ukiyo-e:

The Courtesan after Keisai Eisen (1790-1848), and two other studies after Hiroshige. One of these examples is shown here from Utagawa Hiroshige (1797-1858), his Sudden Shower over Shin-Ōhashi Bridge and Atake from "One Hundred Famous Views of Edo" (1857, Fig. 4-2).

After 1889, Van Gogh spent his final years at a sanatorium in Saint-Paulde-Mausolée in southern France. From a window of his room he could see a field of wheat, which he drew in his paintings almost twelve times. "This picture [Rain (1889, Fig. 4-3)] of the wheat field during a rainstorm is the only work of its kind he did in the South, and while the idea of representing rainfall by diagonal slashes of paint clearly relates to Van Gogh's interest in Japanese prints, the final effect is completely personal and well beyond any borrowed source. There is truly nothing quite like it in his considerable output--truly nothing so gently and objectively observed, nothing so completely revealing his own state of mind" (Rishel 1995, p. 203).

The depiction of the rain from dark sky by black lines seems to be made by Van Gogh for the first among Impressionists. Furthermore, it is interesting that similar expression could be seen in Čiurlionis' Summer (1907, Fig. 4-4). Even though it is more ambiguous and not in straight lines, the rain lines from dark sky could be regarded as an influence from Hiroshige's ukiyo-e print or Van Gogh's paintings.

The American-born painter James Abbott McNeill Whistler (1834-1903) is well-known as an ardent collector of Japanese objects of art and we can easily recognise many Japanese motifs such as kimonos and ceramics in his paintings. Around the same time as Whistler, painters such as Édouard Manet (1832-1883), James Tissot (1836-1902) and Dante Gabriel Rossetti (1828-1882) were fascinated by Japanese arts as early as the $1860 \mathrm{~s}$; however, adopting exotic motifs as eagerly as others, Whistler was outstanding in his originality in consciously introducing the manner of composition peculiar to Japanese art in order to realise his own artistic ideas.

For example, there are obvious resemblances between his painting Variations in Flesh Colour and Green: The Balcony (1864/70) (Fig. 5-1) and Torii Kiyonaga's (1752-1815)'s ukiyo-e, June from "Twelve Months in the South" 
(diptych) (c. 1784, Fig. 5-2). Not only introducing Japanese objects into the painting such as kimonos, shamisen (a guitar-like instrument) and uchiwa (paper fan), Whistler also adopted a whole compositional scheme and scenic setting which takes a broad view from the high ground to the surface of the water. The vertical and horizontal structural outline, a woman who is leaning against the fence and even the Japanese sudare (bamboo blind) hanging from the ceiling were surely inspired by Kiyonaga's ukiyo-e.

Many Polish painters from the Młoda Polska (Young Poland) movement studied abroad and were inspired by the aesthetics of Japonisme and painted works à la japonaise. Sometimes the influence of Japonisme was absorbed through paintings by the Impressionists. For example, Whistler's influence can be found in paintings by two Polish painters. One was Olga Boznańska (1865-1940), who studied art in Munich and was active in Krakow and Paris as a follower of French impressionism. Several Japanese artefacts can be seen in her paintings, such as in her Japanese Woman (1889, Fig. 5-3), in which an influence from Whistler's Symphony in White No. 2 (1864, Fig. 5-4) is present in the white dress and typical Japanese uchiwa [fan]. Another was Wojciech Weiss (1875-1950), who studied at the Academy of Fine Arts in Krakow: his Rózia in Kimono (Date unknown, Fig. 5-5) shows a distant echo of Whistler's famous portrait. In his Musicians (1904, Fig. 6-1), we can easily recognize the influence of Whistler's Nocturne: Blue and Gold - Old Battersea Bridge (ca. 1872-75, Fig. 6-2), the reminiscence of the famous ukiyo-e, Hiroshige's Kyōbashi takegashi from "One Hundred Famous Views of Edo" (1857, Fig. 6-3). What inspired Whistler here was the unique composition adopting a bridge pier in the middle of the painting and the peculiar viewpoint from the river under its arches. These innovative tactics were unseen in earlier Western paintings. The characteristic faded blue tone evoking the silence of the night was undoubtedly taken from Hiroshige's example.

In Whistler's well-known Nocturne in Black and Gold: The Falling Rocket (1874) (Fig. 7-1), pictorial ambiguity was drastically increased and it caused a great deal of controversy. Some resemblances with Hiroshige's Fireworks at Ryōgoku from "One Hundred Famous Views of Edo" (1856-58, Fig. 7-2) are also seen in the common subject matter and its rendering. ${ }^{4}$ Here Whistler learned how to express the "night music" through the interweaving of black colour, light and shade. Thus, the innovative motifs from Hiroshige's ukiyo-e made it possible for Whistler to express his nocturnal idea that "a nocturne is an arrangement of line, form, and colour first" in his paintings. Here we could see how much Whistler got closer to musical thinking in art, which is a gateway to abstract paintings of the coming generation in the early $20^{\text {th }}$ century.

Čiurlionis' Sketch for a Composition (1908, Fig. 7-3) shows strong influence from the above-mentioned Hiroshige's Fireworks at Ryogoku (1856-58). In the Čiurlionis' sketch, a person on a ship is looking at the sky with stars. The 
depiction of the stars seems remarkably similar to Hiroshige's. Moreover, Čiurlionis turned over the stars into his Allegro from "Sonata No. 5 (Sonata of the Sea)" (1908, Fig. 7-4). What noteworthy here is that, similar to Whistler's example, Čiurlionis provided a musical title Allegro from "Sonata No. 5 (Sonata of the Sea)" for the painting. From this point of view, Čiurlionis may have known Whistler's painting, probably under the same influence as above-mentioned Polish painters of Młoda Polska.

Though Čiurlionis never visited London and Paris, from the above-mentioned examples, we could see that he had opportunities to encounter Japanese artworks directly and indirectly. Čiurlionis seemed not as enthusiastic about Japanese arts as were Monet, Van Gogh and Whistler, but it is quite certain that Čiurlionis was one of the artists more or less inspired by Japonisme, the trend throughout Europe during this time.

\section{Hokusai's "Manga" and its influence in Europe}

The name of Hokusai often appeared in the famous French art magazine Gazette des Beaux-Arts in 1870s. The earliest example was an article "Le Japon à Paris" written by Ernest Cheneau (1833-1890) for the commemoration of the Exposition Universelle in Paris 1878. In the article, Cheneau mentioned the characteristics of Japanese art and acclaimed it highly. He especially referred to 15 volumes of Hokusai Manga and emphasized the flat and unsymmetrical expressions of Japanese art which cannot be seen in Western art.

Even though the word 'manga' is regarded as Japanese 'comics' or 'cartoon' nowadays, it was originally used for expressing fanciful and satirical drawings in the Edo period.

Hokusai had started drawing in autumn 1812 at house of Maki Bokusen (1775-1824), a patron and student of Hokusai, Hokusai drew over 300 sketches during half a year. The sketches were published in handbook form as Hokusai Manga from the publisher Eirakuya Tōshirō in 1814 and gained a favourable reception. Originally it was conceived as a reference work for art students, but it became a bestseller at the time and had been published by 1878 in a total of fifteen volumes, consisting of 970 pages with over 4000 illustrations. Hokusai Manga consists of various illustrations from everyday life of human beings, manners and customs, plants and animals, and apparitions in different styles such as caricatures, satirical drawings, multiple-panel illustrations, and narrative depictions, which undoubtedly became the source of inspirations for 'manga' as it is understood nowadays. There was an anecdote about Hokusai Manga that it was first brought to Europe with ukiyo-e prints as cushioning material for ceramics in 1830s and gradually came to the attention of artists.

In Poland, an abundant collection of Japanese artworks was brought by Feliks 
Jasieński (1861-1929, Fig. 8-1), who had stayed in Paris from the mid-1880s where he encountered arts from all over the world, and was especially fascinated by Japanese art. His stay in Paris gave him the opportunity to become acquainted with the latest aesthetic trends, and this experience increased his enthusiasm for collecting oriental art. At the same time, he promoted Japanese art in Poland by holding exhibitions and contributing many articles to major journals. $\mathrm{He}$ published a book titled Manggha, Promenades à travers les mondes, l'art et les idées (1901, Fig. 8-2). The name of "Manggha" is naturally taken from Hokusai Manga. Jasieński also used "Manggha" as his own nickname. His collection of oriental art, donated to the National Museum in Krakow in 1920, consisted of 15,000 objects in total including 6,000 Japanese works. Jasieński considered the 4,500 ukiyo-e prints to be "the most elegant and powerful expression of human spirit" (Martini 1999, pp. 162-166).

A direct influence from Japanese illustration could be admitted in paintings by Ferdynand Ruszczyc (1870-1936), who was from a Polish-Danish family, lived in Lithuania and completed his studies at the Academy of Arts in St. Petersburg. He encountered Japanese art at an exhibition during his studies there. According to his letters to Jasieński, he was especially fascinated by Hiroshige's ukiyo-e landscapes and adopted his way of depiction in his own paintings (Martini 1999, pp. 172-177). In his Winter Fairytale (1904, Fig. 9-1), the snowscape itself suggests the influence of Japanese art, and the resemblance of the shapes of the branches to an illustration from Hokusai Manga (Fig. 9-2) is hardly accidental. Interestingly, a similar representation of a tree appears in Čiurlionis' etching Leafless Tree (1905-06, Fig. 9-3).

As seen above, direct and indirect influences from Japonisme could be seen in paintings of many artists within the Młoda Polska movement. Even though Poland is a long distance from London and Paris, then the artistic centres of Europe, the aesthetics of Japonisme had surely reached there in the 1890s, and been absorbed by artists who were active in Poland including Čiurlionis.

Some paintings shown below are just the hypothetical examples that suggest that Čiurlionis seems to have referred some compositional and representational ideas from Hokusai Manga.

Čiurlionis' painting, The Sea (1906, Fig. 10-1) could be considered to be drawn under the influence from an illustration depicting the waves of the sea in Hokusai Manga (Fig. 10-2). What is interesting here is that Čiurlionis turned the waves into the field of wheat in his other painting, Adoration of the Sun (1909, Fig. 10-3) in which he depicts the shade of an elephant implying an Asian image in the background of the painting. Waves are a basic motif for painters, so it cannot be said with absolute certainly, but the shapes of the waves show considerable similarity in these works by Čiurlionis and Hokusai. 
Some parts of Hokusai Manga consist of illustrations from people's movements in everyday life. Two pages are devoted exclusively to showing people bending bows with Japanese-style archery (kyūdo) (Fig.11-1). Čiurlionis also left sketches of people who are bending bows with Western style archery in his Sketches for Sagittarius and Scorpio from cycle of 12 paintings "The Zodiac" (1906, Fig. 11-2), completed as The Sun is Passing the Sign of Sagittarius (1906/ 07, Fig. 11-3). Even though, there are different styles of archery in Japan and the West, the fact that both Hokusai and Čiurlionis depicted the movement of people bending bows shows an interesting conceptual coincidence between East and West.

In Russia, Japonisme flourished a bit later than Europe at the end of 1890s. Although Russia is the closest country to Japan, Japanese art works were imported there mainly via European cities such as Paris or Munich. Like Jasieński in Poland, Russia had an ardent collector of Japanese art, Sergey Kitaev (1864-1927), a naval officer. He had chances to visit Japan in the course of his duties in 1885-96, and collected 6,000 works in total. Now his collection belongs to the Pushkin State Museum of Fine Arts in Moscow (The Pushkin State Museum of Fine Arts, 2011-2013).

Kitaev's collection was exhibited several times in 1896, 1897 and 1905. The last exhibition was organized by Nicholas Roerich (1874-1947), a famous painter who acted as the leader of Mir Iskusstva (World of Art) movement in 1910-1916. Roerich encountered Japanese art at Kitaev's exhibition in 1896 when he was a student at the Academy of Arts in St. Petersburg. From that time, he championed Japanese art by writing articles for several journals and newspapers.

Mstislav Dobuzhinsky (1875-1957) was the very person who introduced Čiurlionis to the artists of Mir Iskusstva. In his reminiscence on Čiurlionis, Dobuzhinsky recalled when Čiurlionis was in St. Petersburg:

I spoke of the [Čiurlionis'] paintings I had seen to my friends, whose interest was greatly aroused, and before long I invited A. Benois, Somov, Lansare, Bakst, and Sergei Makovsky (editor of the journal Apollon) to show them all the works that Čiurlionis had brought with him. [...] Čiurlionis' works amazed everyone first of all with their originality and singularity - he resembled no other painters - and the source of his art seemed profound and mysterious (Goštautas (ed.) 1994, pp. 160-161).

Moreover, Dobuzhinsky wrote about Čiurlionis: "In my home, he was a frequent guest. [...] Čiurlionis apparently felt comfortable and at ease with my family [...] I had a good library of art books and a great many engravings" (Goštautas (ed.) 1994, p. 162). Therefore, together with above-mentioned Hokusai Manga, there must have been some opportunities for Čiurlionis to absorb the aesthetics of ukiyo-e from Dobuzhinsky's library as well as through the members of Mir Iskusstva. 
Some of Čiurlionis' paintings show strong resemblances to specific ukiyo-e of Hokusai and Hiroshige in their pictorial schemes and fragmentary uses of motifs. What is that Čiurlionis is different from other painters in accomplishing a personal approach to ukiyo-e, by adopting the whole composition and the characteristic point of view.

Among the active members of Mir Iskusstva, Russian painters such as Igor Grabar and Mstislav Dobuzhinsky studied in Munich and became great admirers of Japanese art. After their return to Russia, Japonisme was indeed one of the group's notable artistic traits.

There are some descriptions on Japanese art found in Dobuzhinsky's memoirs:

I am thankful to Grabar for my first acquaintance with Japanese art - in his collection in Munich I saw woodcut prints of Hokusai, Hiroshige and Utamaro. He had already new examples. In 1902, a small and joyful Japanese person, Hasegawa, appeared in St. Petersburg. He spoke little Russian, but visited a lot of artists here and brought perfect Japanese woodcut prints. Everybody bought them from him with enthusiasm, because the prices were not high. [...] I bought only several woodcut prints and a book of Hokusai's 'Manga'. Especially I was fascinated by Hiroshige because of his unexpected composition and decorative landscapes. For me, the view from the corner and 'cutting of nature' were the biggest discoveries (Dobuzhinsky 1987, p. 192).

\section{The application of Japonisme in Čiurlionis' paintings}

As mentioned above, Čiurlionis went to see two exhibitions of Japanese art during his studies in Warsaw. It is possible that Čiurlionis saw Japanese art directly at these exhibitions in 1900-01. Moreover, he had a chance to be acquainted with members of Młoda Polska (Young Poland) movement, who almost all studied in Paris, London, Munich or Vienna and absorbed the aesthetics of Japonisme in these cities. Čiurlionis must have been in touch with Japonisme trends and its aesthetics. His own travel to Prague, Dresden, Nuremberg, Munich, and Vienna in 1906 may have affected on his style of paintings after 1907.

In this chapter, the influence from Japonisme in Čiurlionis' paintings will be considered in three stages: the first stage is partial borrowing of exotic japonaiserie motifs. The second is the stage of application of ukiyo-e's pictorial schemes or whole compositions into his paintings, and finally, in the stage of borrowing and application, there appears the elaborate assimilation of ukiyo-e's expressions into his own sublime style.

First, some examples of japonaiserie motifs in Čiurlionis' early paintings should be considered. In Ciurlionis', Night, from the cycle of 10 paintings 
"Fantasies" (1904/ 5, Fig. 12-1), there is a depiction of a bridge whose peculiar shape strongly reminds us of the gate of a Japanese shrine (torii) such as we can see in Hiroshige's The Fork of Akiba in Kakegawa (1843-47, Fig. 12-2). Torii is a very popular type of gate in Japan and is depicted in many other ukiyo-e prints. Therefore, Čiurlionis may have seen another example of this kind of ukiyo-e, and adopted it as a motif in his paintings.

The next example of a motif shows a somewhat strange interest of Čiurlionis'. In Spring Motif (1907, Fig. 13-1), the shapes of clouds are depicted in a very different way from his other paintings. It is most likely that Čiurlionis adopted the characteristic depiction of clouds from Hokusai's famous Mount Fuji Viewed during a Fine Wind on a Clear Morning from "Thirty-Six Views of Mount Fuji" (c. 1829-1833, Fig. 13-2).

Likewise, the image of a big bird hovering in the sky in Ciurlionis' Fairy Tale No. 2 from cycle Triptych "Fairy Tale" (1907, Fig. 14-1), and Hiroshige's Susaki and the Jümantsubo Plain near Fukagawa from "One Hundred Famous Views of Edo" (1856-58, Fig. 14-2), are compositional concepts. ${ }^{5}$

When we compare Čiurlionis' Finale, from the cycle "Sonata No. 2 (Sonata of the Spring)" (1907, Fig. 15-1) with Hiroshige's The City Flourishing, the Tanabata Festival from "One Hundred Famous Views of Edo" (1856-58, Fig. 15-2), similarities can be found between the colourful papers (or small flags?) flying in spiral in both images.

As another example, in Čiurlionis' Allegro from "Sonata No. 3 (Sonata of the Serpent)" (1908, Fig. 16-1), the strange shape of the maze-like bridge and its long bridge footings may have been influenced by Hokusai's Old View of the Eight-part Bridge at Yatsuhashi in Mikawa Province from "Remarkable Views of Bridges in Various Provinces" (1834, Fig. 16-2). Many similar bridges were depicted in Hokusai's several other ukiyo-e prints, but the similarity of concepts between Čiurlionis and Hokusai is surely undeniable.

As the second stage, let us look at the whole composition or settings. In Čiurlionis' Allegro from "Sonata No. 4 (Summer Sonata)" (1908, Fig. 171), tiny sailing boats floating on the water and the position of islands may be inspired by Hiroshige's Shinagawa Susaki from "One Hundred Famous Views of Edo" (1856-58, Fig. 17-2).

Furthermore, the triptych painting Raigardas (1907, Fig. 18-1), which is known as a realistic landscape of peacefully gentle hills in the Sothern Lithuania, shows some quite unusual features. An attempt to produce panoramic scenery by using three panels sequentially is very unusual among his existing paintings. However, in ukiyo-e, it is not rare to use two or three successive papers to represent the spatial dimension and the effect of a bird's eye view. For example, if we put Hiroshige's triptych Whole View of Asukayama from "Famous Views of the Eastern Capital" (c. 1835-39, Fig. 18-2) beside Čiurlionis' Raigardas, both panoramic scenes seem remarkably similar. He may have seen this kind of triptych of ukiyo-e in Warsaw or elsewhere. 
In Čiurlionis' paintings, several traces of influence from ukiyo-e of Hokusai and Hiroshige can be found in its pictorial schemes and fragmentary uses of motifs. Čiurlionis differs from other painters in that whenever he absorbed Japanese ukiyo-e, he accomplished his personal approach by adopting the whole composition and the characteristic point or view.

Finally, as the third stage, let us consider the sublime style of Čiurlionis' "Great Wave" motif adopted in his painting Finale from "Sonata No. 5 (Sonata of the Sea)" (1908, Fig. 1-1). The influence of Hokusai's The Great Wave off Kanagawa was firstly pointed out by Ichiro Kato (1930-2003) in 1976 (Kato 1976, pp. 40-44). Since then, many scholars have followed him and accepted it as a fact. ${ }^{6}$ The most unique and extraordinary feature in this picture is that he put his initials "MKC" symbol identifying his own high creativity. Since Čiurlionis seldom signed his paintings, this painting is very rare in that he drew his large initials in such an eye-catching position. Moreover, the characters are integrated in the wave of the central motif. Čiurlionis, as a composer, was following the tradition of Western music to compose in tone rows based on the spelling of someone's name. ${ }^{7}$ There are many composers who adopted their own initials as the hidden theme of compositions such as Bach's B-A-C-H. Considering this heritage, CCiurlionis might have proudly put his initials into the "musical painting" as a proof of himself as a composer-painter. The gigantic waves which involve the whole may be the symbol of his strong creative motivation. Furthermore, there is a remarkable fact that the series Sonata of the Sea: Allegro, Andante and Finale lets us feel an inner link with his musical work, The Sea: Cycles of Small Landscapes for piano (1908). The first piece of the cycles, I (VL 317a) could be heard as expressing the constantly repeated waves in the painted Allegro, the second piece, II (VL 317b) evokes the mysterious and silent image of the sea in the painted Andante, and in the third piece (VL 317c), the chromatic scales could be heard as breaking gigantic wave of painted Finale.

\section{Conclusion}

As we have seen in this paper, it is true that the prime period of Japonisme in Europe was the rather short time from the late $19^{\text {th }}$ century to the beginning of the $20^{\text {th }}$ century. However, the momentum of the time helped Japonisme to be a stronger trend especially among artists in Paris. Not only Impressionist painters but also poets and composers were influenced by Japonisme and collected Japanese artworks. Impressionist painters and contemporaries such as Monet, Van Gogh and Whistler absorbed ukiyo-e prints as a model of some of their paintings and partially borrowed japonaiserie motifs, applying ukiyo-e's pictorial schemes or 
whole compositions. Surprisingly, not only ukiyo-e prints by Hokusai and Hiroshige, but also Hokusai Manga were well appreciated among the bourgeoisie in Warsaw, Moscow and St. Petersburg, and were mentioned in several autobiographies of artists at the time.

Even though Čiurlionis never visited Paris or London, it seems quite certain that he came to know Japonisme through the artists of Młoda Polska and the Japanese art collection of Jasieński during his studies in Warsaw. Moreover, he was on the same trend as the Impressionists, borrowing japonaiserie motifs from the same ukiyo-e as Impressionists and applied them to his paintings in his own way.

Ciurlionis was a talented painter, full of imagination. It may have been noticed in his paintings shown in this paper that, even though Čiurlionis borrowed japonaiserie motifs from ukiyo-e prints by Hokusai and Hiroshige, his way of applying the motifs was considerably different from other contemporary painters and unique to him. Čiurlionis' paintings contain complex mixtures of the influences from various cultures in different times. It is not an easy task to point out clear signs of inspiration from ukiyo-e or adoptions of Japanese motifs in each individual work. The paintings described in this paper were just the hypothetical examples where Čiurlionis seemed to have referred to some compositional and representational ideas from ukiyo-e. However, it could be said that some of these coincidences between ukiyo-e and Čiurlionis' work should not be regarded as mere chance resemblances.

Even though, Čiurlionis" "Great Wave" in his painting Finale from "Sonata of the Sea" showed the influence from Hokusai's "Great Wave" like the major artists active in Paris, his version was painted in Palanga, Lithuania in July 1908. We must not forget that Čiurlionis' strong affection for his country were expressed in his works conceived beside the forest of Lithuania and the Baltic seashore. It could be said that the wave from Japan met the wave from Baltic Sea in the Čiurlionis' painting, giving a strong expressive impact as a synergistic effect.

\section{References}

\section{Books:}

Andriušytė-Žukienè, R., 2004. M. K. Čiurlionis: Tarp Simbolizmo ir Modernizmo: Monografija. Vilnius: Versus Aureus.

Dobuzhinsky, M. V., 1987. Воспоминания: М. В. Добужсинский (Memories: M. V. Dobuzhinsky). Moscow: Nauka.

Dorment, R. and MacDonald, M. F., 1994. James McNeill Whistler. London: Tate Gallery Publications.

Galaunè, P. ed., M. K. Čiurlionis. Kaunas: Vytauto Didžiojo Kultūros Muziejaus M. K. Čiurlionies Galerija, 1938. 
Goštautas, S. ed., 1994. Čiurlionis: Painter and Composer, Collected Essays and Notes, 1906-1989. Vilnius: Vaga.

Hofstätter, H. H., 1965. Symbolismus und die Kunst der Jahrhundertwende (Symbolism and art of the turn of the century). Cologne: Dumont.

Kikuchi, S. ed., 1980. Porando hizo ukiyo-e meisakuten (Exhibition of ukiyo-e Masterpieces in Polish Collection: exhibition catalogue). Tokyo: Kyodo Tsushin.

Koval, A., 1994. Whistler in His Time. London: Tate Gallery Publications.

Król, A., 2007. An Image of a Floating World: Japanese Art Inspirations in the Paintings of Jan Stanistawski and his Student. Krakow: Manggha Centre of Japanese Art and Technology.

Król, A., 2011. Polish Japanism. Krakow: Manggha Centre of Japanese Art and Technology.

Landsbergis, Vytautas, 1992. M. K. Čiurlionis. Time and Content. Vilnius: Lituanus.

Maur, K. ed., 1999. The Sound of Painting. Munich: Prestel.

Mabuchi, A., 1997. Japonisumu: Genso no nippon (Japonisme: Représentations et Imaginaires des Européen). Tokyo: Brücke.

Molodiakov, V., 2011. Japonizumu no roshia: shirarezaru nichiro bunka kankeishi (Russian Japonisme: Unknown History of Japanese-Russian Cultural Relations). Tokyo: Fujiwara Shoten.

Ono, A., 2003. Japonisme in Britain: Whistler, Menpes, Henry, Hornel and nineteenthcentury Japan. London: Routledge Curzon.

Pšibilskis, V. B. ed., 2006. Atsiminimai apie M. K. Čiurlioni (Memories of M. K. Čiurlionis).Vilnius: aidai mmvi.

Rishel, J. J., 1995. Philadelphia Museum of Art: Handbook of the Collections. Philadelphia: Philadelphia Museum of Art.

Ryżewska, E. ed., 2007. View of Kościuszko Mound from the Artist's Study Window: Japanese Art Inspirations in the Work of Stanisław Wyspiański. Krakow: Manggha Centre of Japanese Art and Technology.

Urbonas, S. and Andrijauskas A., 2003. М. К. ЧЮРЛЁНИС: Время признания. Vilnius: Kronta.

Sekiguchi, T. ed., 1990. Porando no nippon ten (Japan in the fin-de-siècle Poland: Feliks Jasieński's Collection of Japanese Art and Polish Modernism) (exhibition catalogue). Tokyo: JCC.

Sugimoto, R. ed., 1999. Porando Kurakufu Kokuritsu Hakubutsukan: Ukiyo-e meihin ten (Ukiyo-e from Cracow revisiting Japan) (exhibition catalogue). Gifu: Gifu City Museum of History.

\section{Aricles}

Alber, Z., 1990. The Feliks Jasieński's Collection in the National Museum of Cracow. In: T. Sekiguchi, ed. Porando no nippon ten (Japan in the fin-de-siècle Poland: Feliks Jasieński's Collection of Japanese Art and Polish Modernism) (exhibition catalogue), Tokyo: JCC, pp. 14-17.

Andrijauskas, A., 2011. M. K. Čiurlionis and the East. Lituanus, vol. 57, nr. 4, pp. 65-78. 
Andrijauskas, A., 2013. M. K. Čiurlionis and the East: Part 2. Lituanus, vol. 59, nr. 2, pp. 30-43.

Andriušytė-Žukienè, R., 2009. The Work of Čiurlionis in the Context of Early TwentiethCentury Art. In: R. Andriušytė-Žukienè, ed. Dialogue of Colour and Sound, Works by Mikalojus Konstantinas Čiurlionis and His Contemporaries (exhibition catalogue, Vilnius: Lithuanian Art Museum), pp. 150-160.

Dobuzhinsky, M., 1994. Čiurlionis in St. Petersburg (1908-1909). In: S. Goštautas, ed. Ciurlionis: Painter and Composer, Collected Essays and Notes, 1906-1989. Vilnius: Vaga, 1994, pp. 160-284.

Kato, I., 1976. Mikalojus Konstantinas Čiurlionis, the Lithuanian Composer and Painter, and the Correlation between Pictorial and Musical Compositions. Journal of Baltic Studies, vol. 7, nr. 1, pp. 40-44.

Martini, M., 1999. Feliks 'Manggha' Jasieński and his Oriental Collection. Ukiyo-e from Cracow revisiting Japan. Translated by K. Malcharek (exhibition catalogue). Gifu: Gifu City Museum of History, pp. 162-66.

\section{Websites}

Andriušytė-Žukienė, R., 2006. Influences of "Młoda Polska" [Young Poland] on Early Čiurlionis Art. Lituanus, Vol. 52, nr. 1. Available at:

$<$ http://www.lituanus.org/2006/06_1_05\%20Zukiene.htm $>$ [Accessed on 17 February, 2014].

Burleigh-Motley, M., 2007-2013. Dobuzhinsky, Mstislav. Available at:

$<$ http://www.oxfordartonline.com $>$ [Accessed on 17 February, 2014].

Ford-Wille, C., 2007-2013. Polish Art. Available at:

$<$ http://www.oxfordartonline.com $>$ [Accessed on 17 February, 2014].

Milner, J., 2007-2013. World of Art. Available at:

$<$ http://www.oxfordartonline.com $>$ [Accessed on 17 February, 2014].

Newall, C., 2007-2013. Crane, Walter. Available at:

$<$ http://www.oxfordartonline.com $>$ [Accessed on 17 September, 2014].

Pushkin State Museum of Fine Arts, Japanese Prints of the XVIII - XIX century, 2011-2013. Available at:

$<$ http://www.japaneseprints.ru/reference_materials/articles/public1.php?lang=en 20112013> [Accessed on 15 March, 2014].

Taylor, K., 1996. The Gustav Holst Website. Available at:

$<$ http://www.gustavholst.info/> [Accessed on 29 March, 2014].

University of Glasgow, 2011. The Correspondence of James McNeill Whistler. Available at: $<$ http://www.whistler.arts.gla.ac.uk/correspondence/> [Accessed on May, 5th 2011]. 
Appendix

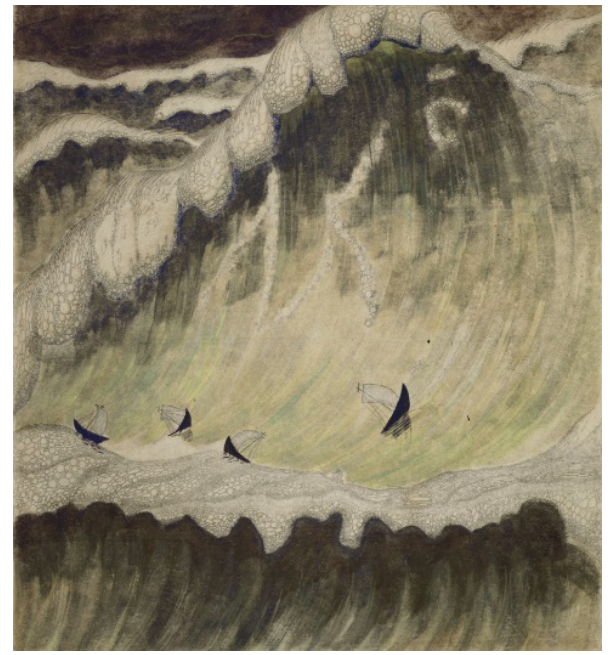

Fig. 1-1 Mikalojus Konstantinas Ciurlionis (1875-1911), Finale from "Sonata No. 5 (Sonata of the Sea)" (1908), National M. K. Ciurlionis Art Museum, Kaunas

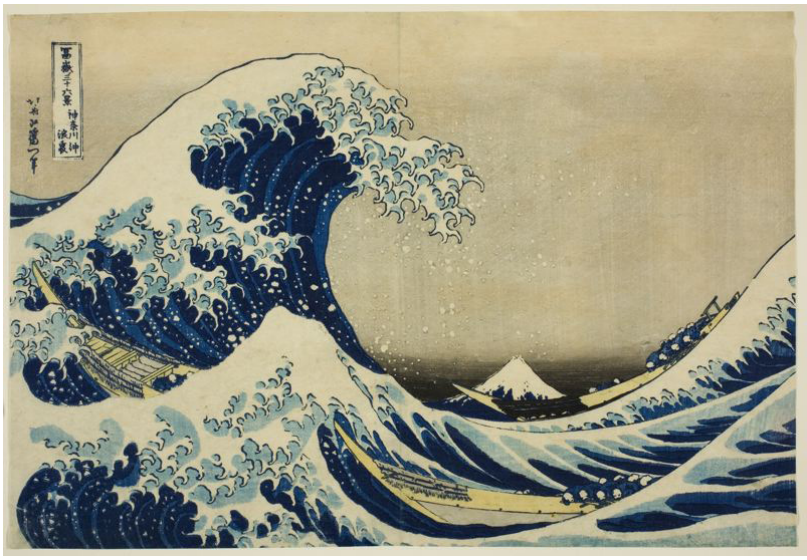

Fig. 1-2 Katsushika Hokusai (1760-1849), The Great Wave off Kanagawa from "Thirty-Six Views of Mount Fuji" (ca. 1831-33), Private collection

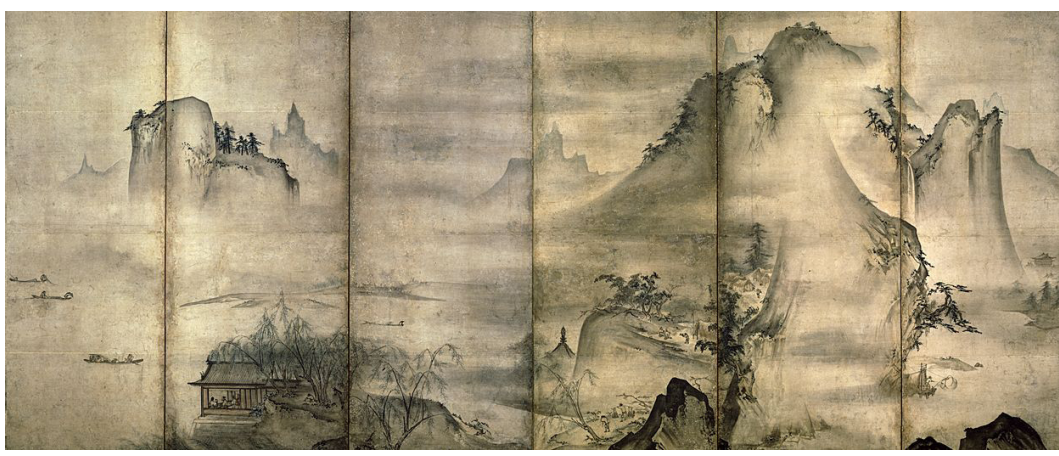

Fig. 1-3 Attributed to Shübun (Dates of birth and death unknown) Landscape of the four seasons (Muromachi Period/ 15th century), Tokyo National Museum 


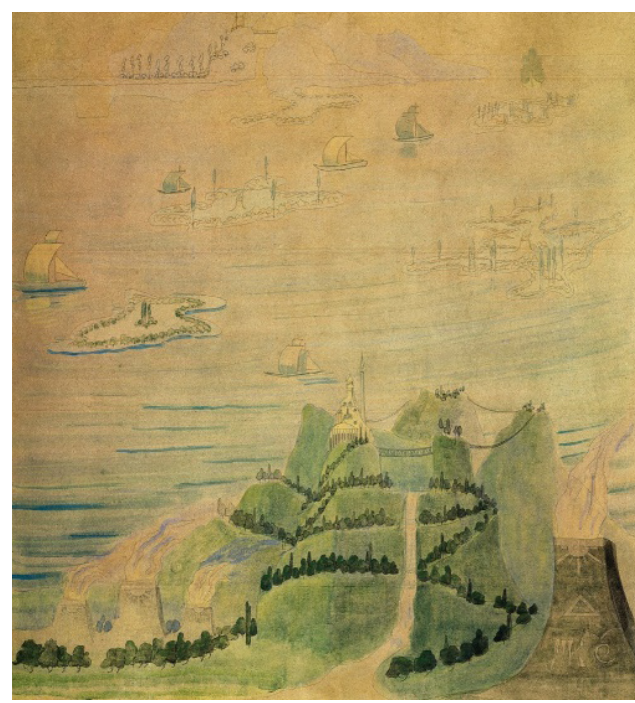

Fig. 1-4 Mikalojus Konstantinas Ciurlionis (1875-1911), Allegro from "Sonata No. 4 (Sonata of the Summer)" (1908), National M. K. Ciurlionis Art Museum, Kaunas

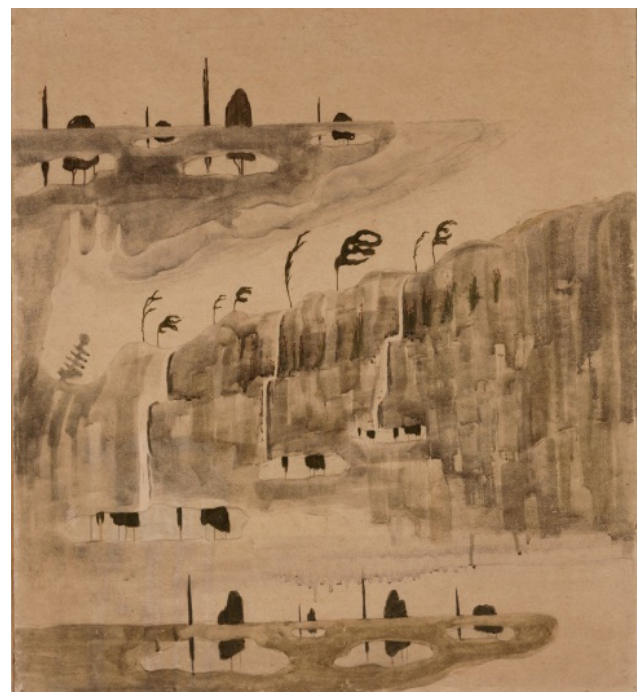

Fig. 1-6 Mikalojus Konstantinas Ciurlionis (1875-1911), Allegro from "Sonata No. 2 (Sonata of Spring)" (1907), National M. K. Ciurlionis Art Museum, Kaunas

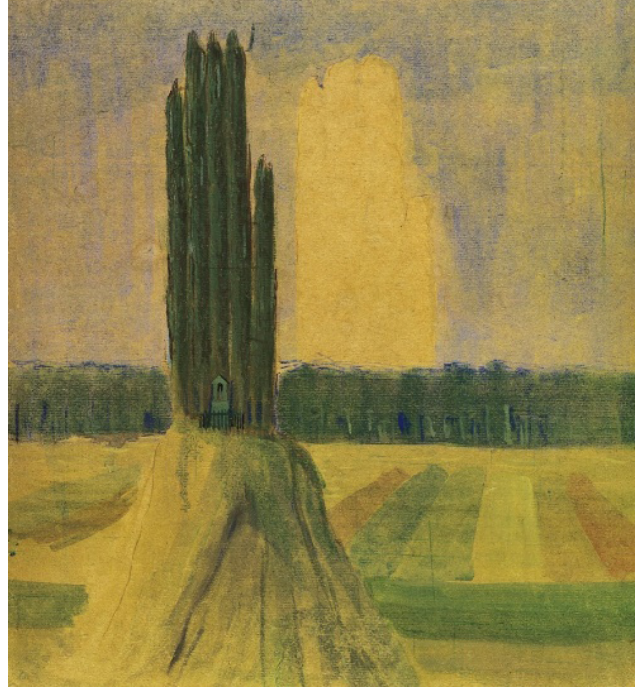

Fig. 1-5 Mikalojus Konstantinas Ciurlionis (1875-1911), Summer II (1907), National M. K. Čiurlionis Art Museum, Kaunas 


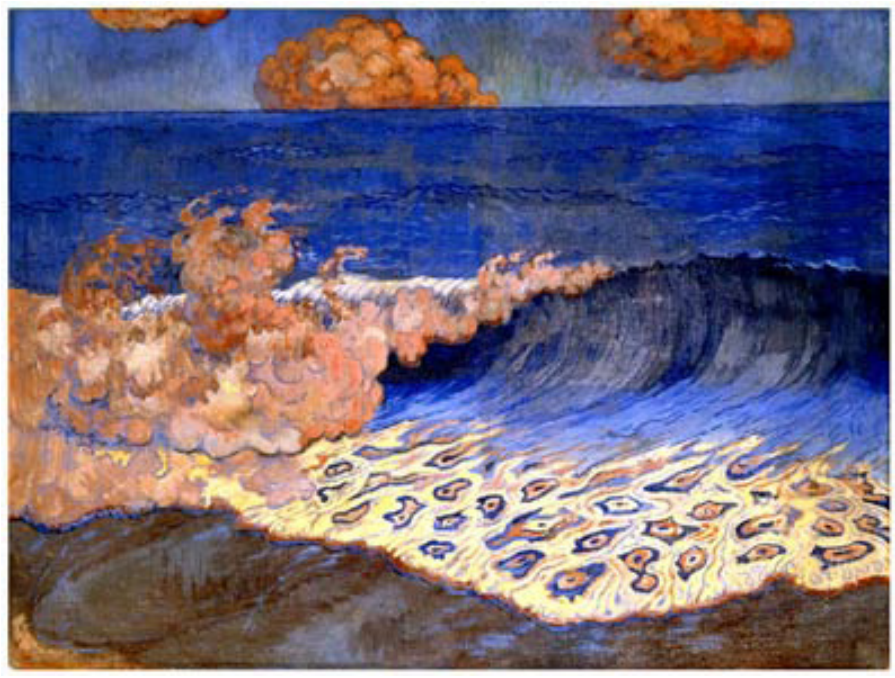

Fig. 2-1 Georges Lacombe (1868-1916), Blue Seascape, Effect of Wave (ca. 1893), Musée des Beaux-Arts, Rennes

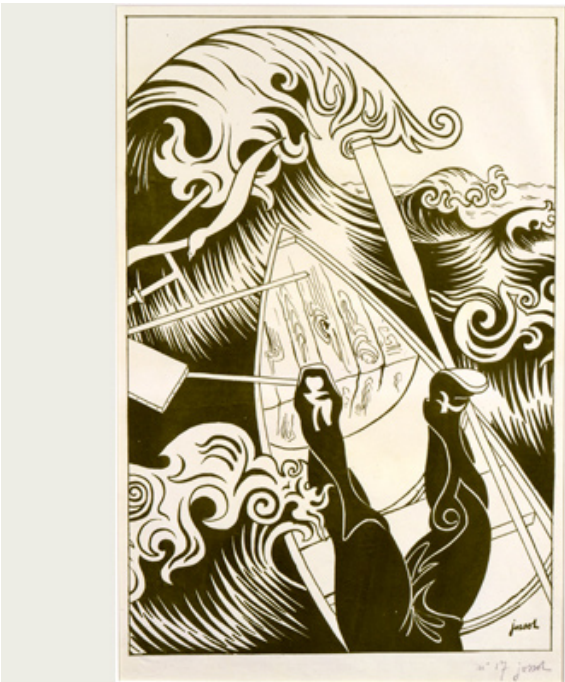

Fig. 2-2 Henri-Gustave Jossot (18661951), The Wave (1891), Collection Zimmerli Art Museum, Rutgers, New Jersey

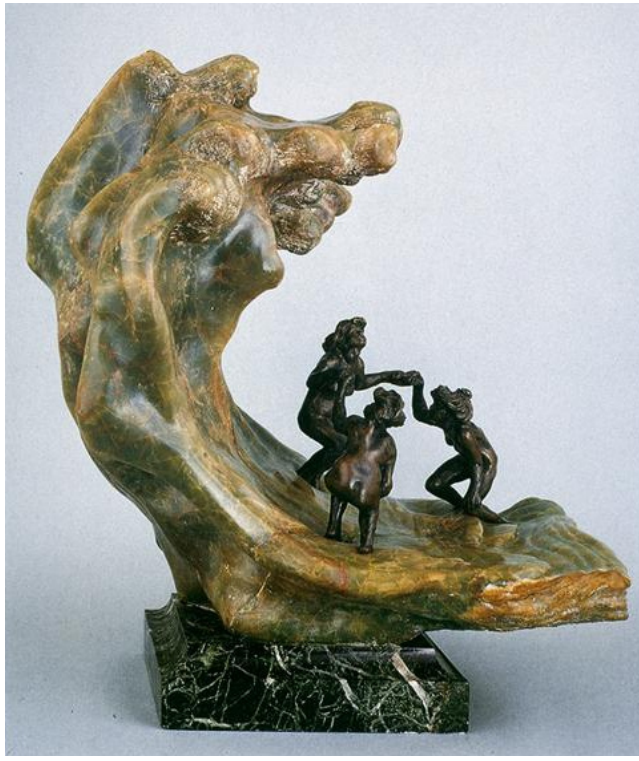

Fig. 2-3 Camille Claudel (1864-1943), The Wave or The Bathers (ca. 18931903), Musée Rodin, Paris 


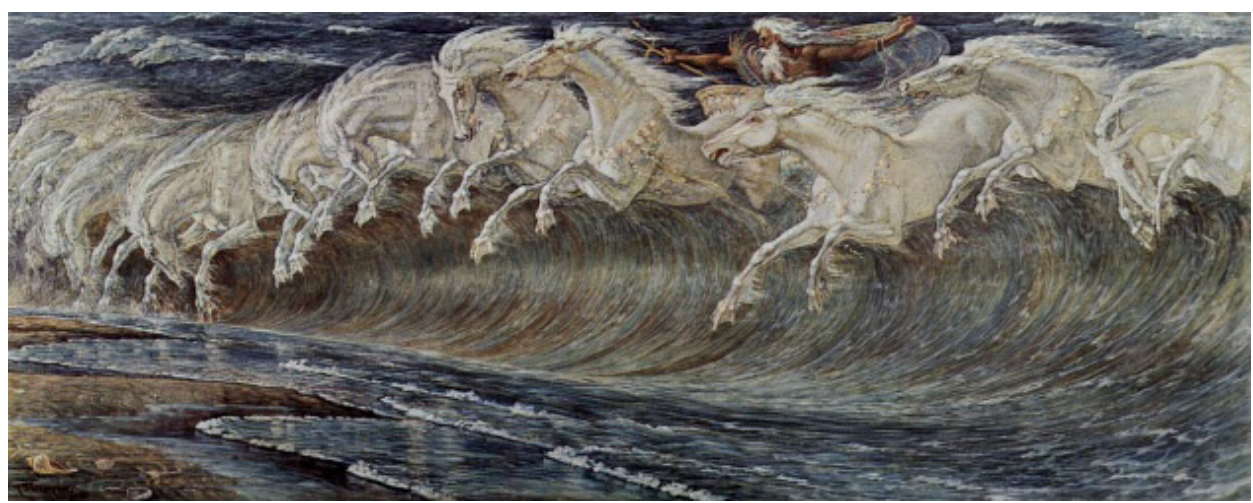

Fig. 2-4 Walter Crane (1845-1915), Neptune's Horses (1892), Neue Pinakothek, Munich

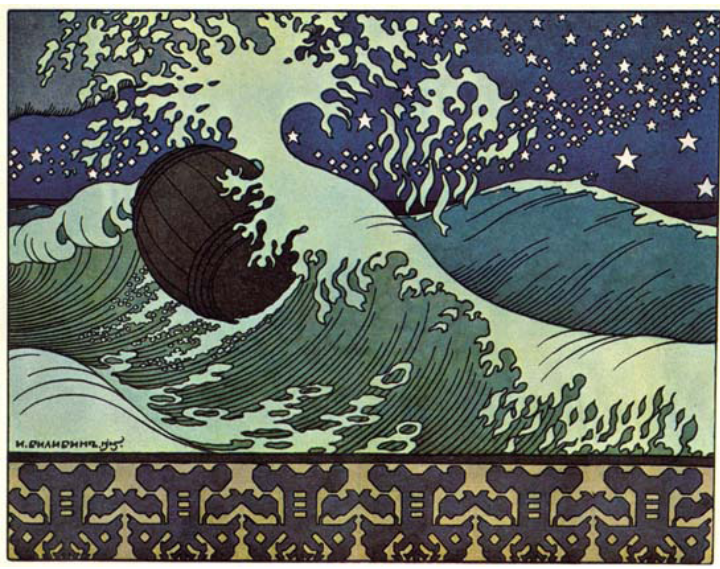

Fig. 2-5 Ivan Bilibin's illustration from the picture book, "The Tale of Tsar Saltan" (1905), Private collection

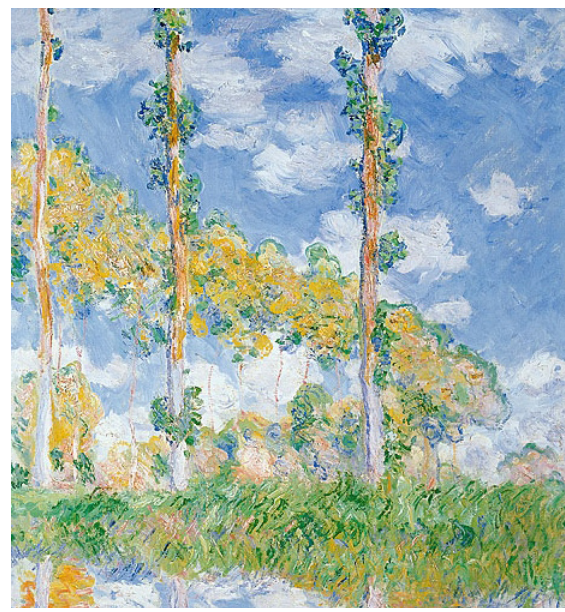

Fig. 3-1 Claude Monet (1840-1926), Poplars in the Sun (1891), The National Museum of Western Art, Tokyo 


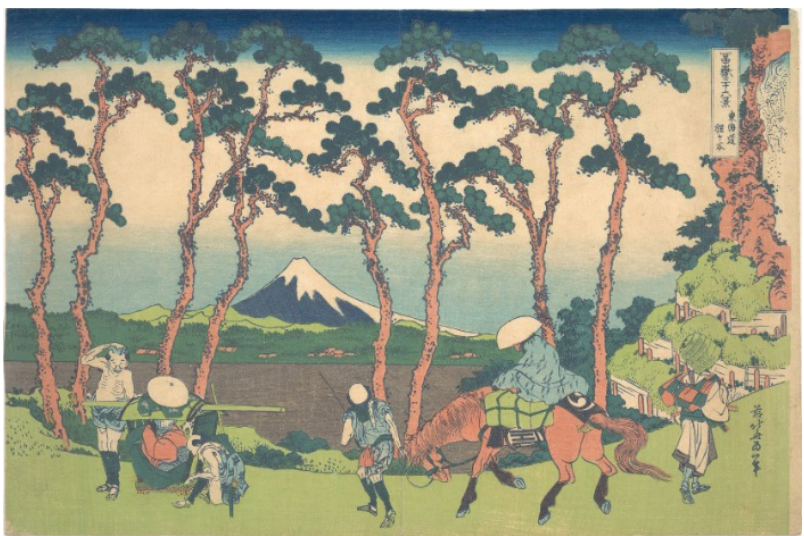

Fig. 3-2 Katsushika Hokusai (1760-1849), Hodogaya on the Tōkaidō, from "ThirtySix Views of Mount Fuji" (ca. 1830-32), Private collection

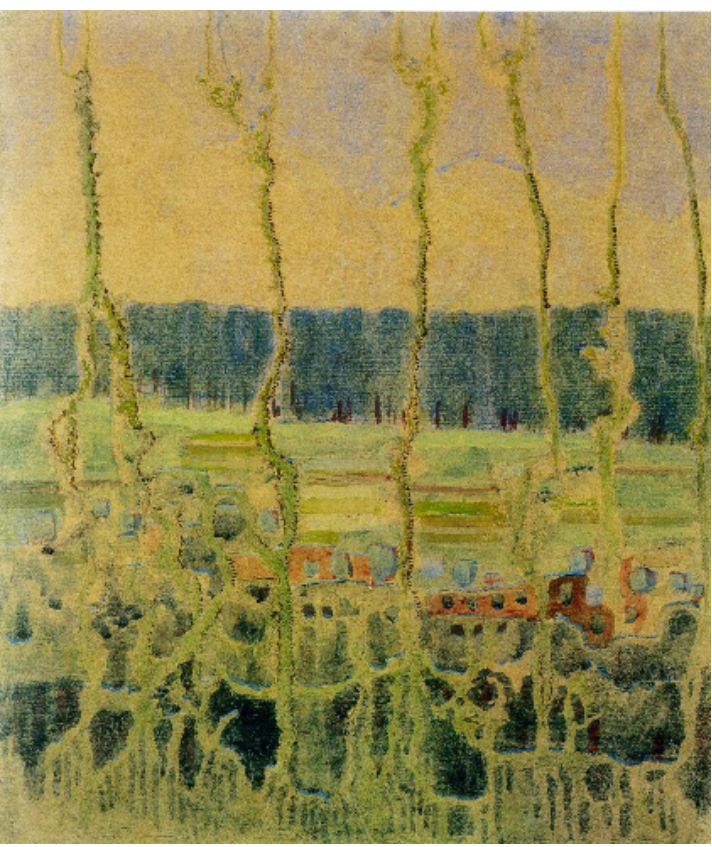

Fig. 3-3 Mikalojus Konstantinas Ciurlionis (1875-1911), Summer I from the triptych (1907), National M. K. Čiurlionis Art Museum, Kaunas

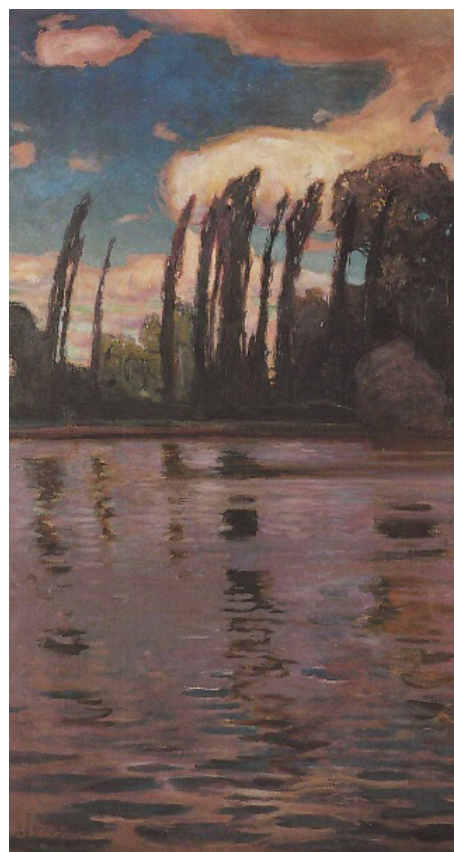

Fig. 3-4 Jan Stanistawski (18601907), Poplars on the Water (1900), National Museum, Krakow 


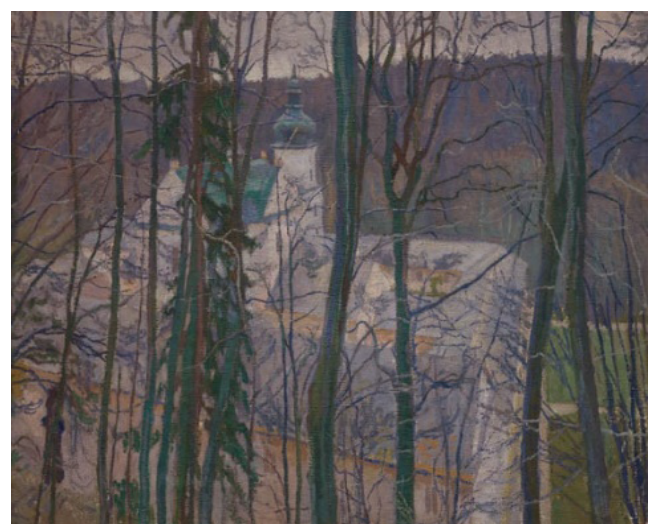

Fig. 3-5 Stanisław Kamocki (1875-1944) View over the Monastery at Czerna (1908), National Museum, Krakow

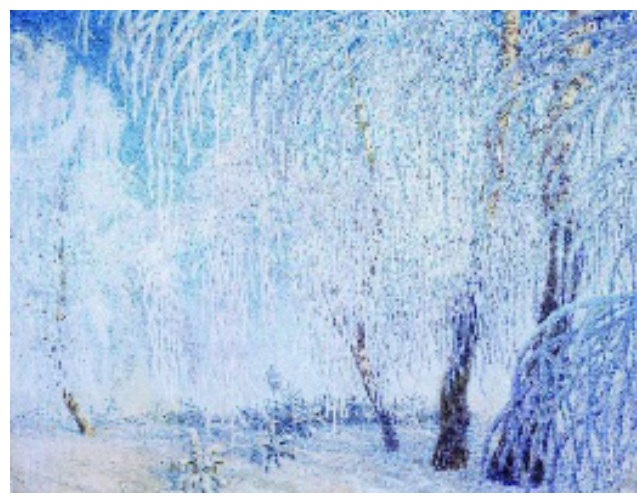

Fig. 3-7 Igor Grabar (1871-1960), The Frost (1905), The Art Museum, Yaroslavl

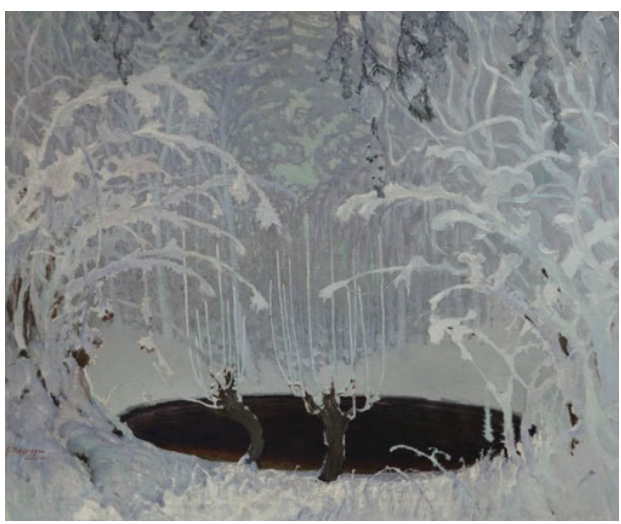

Fig. 3-6 Ferdynand Ruszczyc (18701936) Winter Tale (1904), National Museum, Krakow

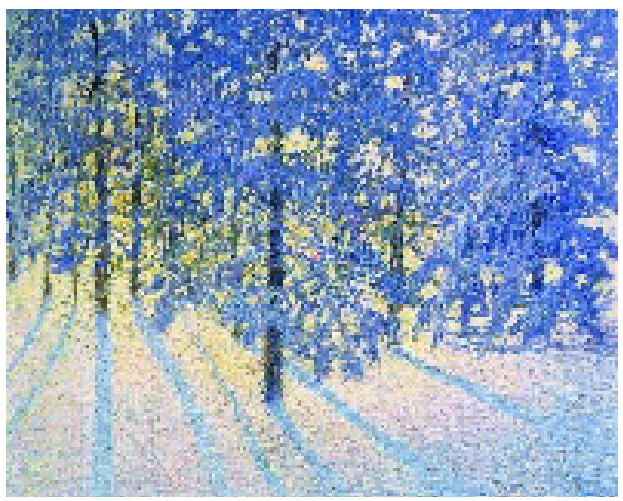

Fig. 3-8 Igor Grabar (1871-1960), Winter Morning (1907), The Art Museum, Sevastopol 


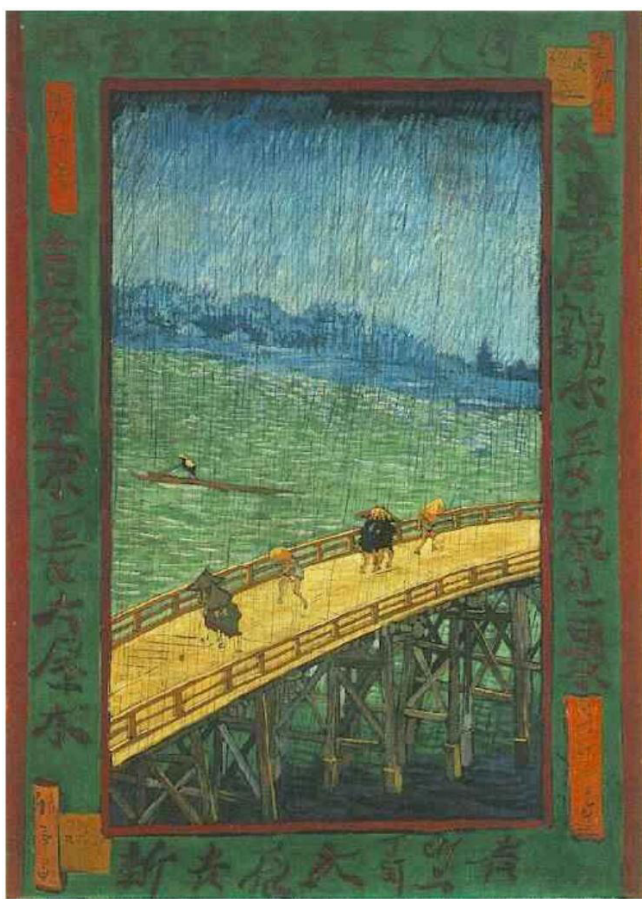

Fig. 4-1 Vincent van Gogh (1853-1890), Japonaiserie: Bridge in the Rain (after Hiroshige) (1887), Van Gogh Museum, Amsterdam

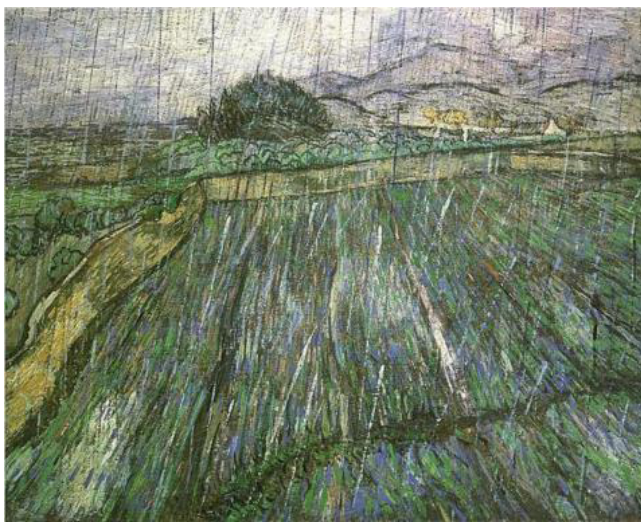

Fig. 4-3 Vincent van Gogh (1853-1890), Rain (La Pluie) (1889), Philadelphia Museum of Art

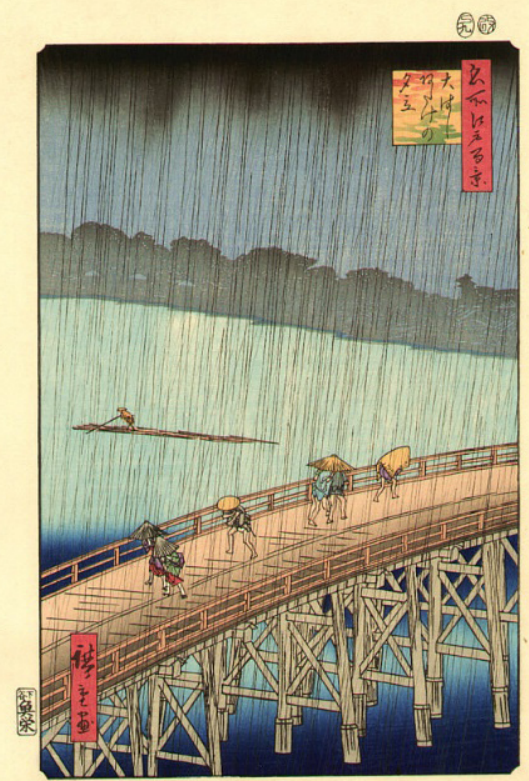

Fig. 4-2 Utagawa Hiroshige (17971858), Sudden Shower over ShinŌhashi Bridge and Atake from "One Hundred Famous Views of Edo" (1857), Private collection

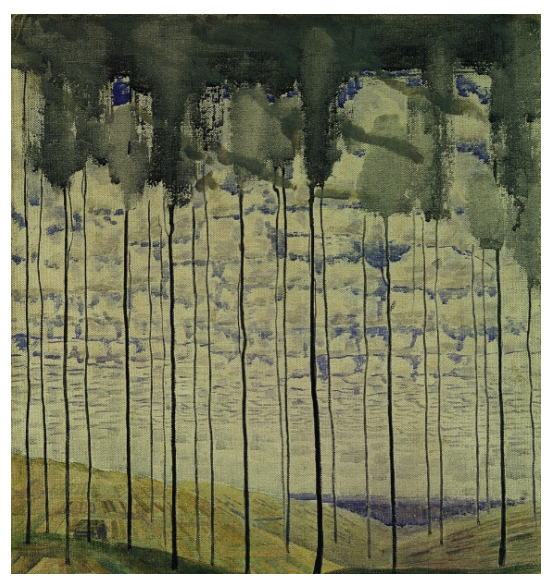

Fig. 4-4 Mikalojus Konstantinas Ciurlionis (1875-1911), Summer (1907), National M. K. Čiurlionis Art Museum, Kaunas 


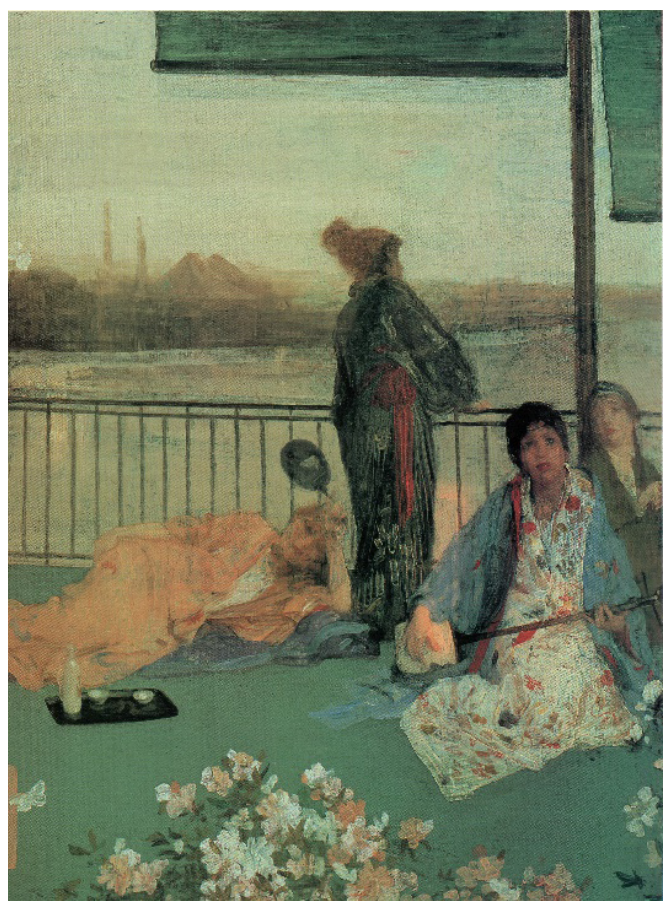

Fig. 5-1 James Abbott McNeill Whistler (1834-1903), Variations in Flesh Colour and Green: The Balcony (1864/70), Freer Gallery of Art, Washington D.C.

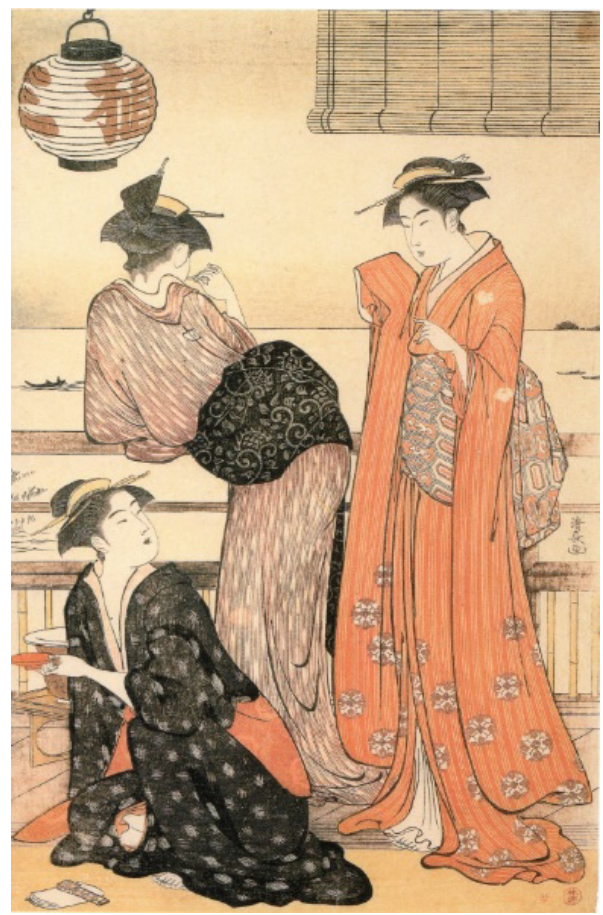

Fig. 5-2 Torii Kiyonaga (1752-1815), June from "Twelve Months in the South" (diptych) (c. 1784), Private collection

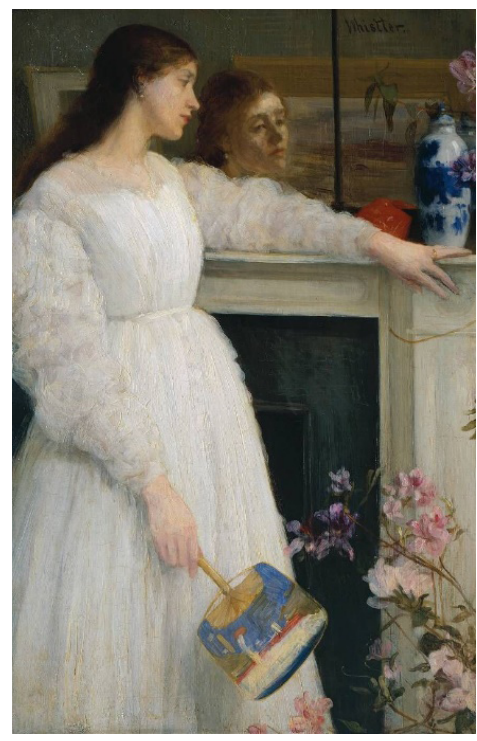

Fig. 5-3 James Abbott McNeill Whistler (1834-1903), Symphony in White No. 2 (1864), Tate Gallery, London

Fig. 5-4 Olga Boznańska (18651940), Japanese Woman (1889), Private collection

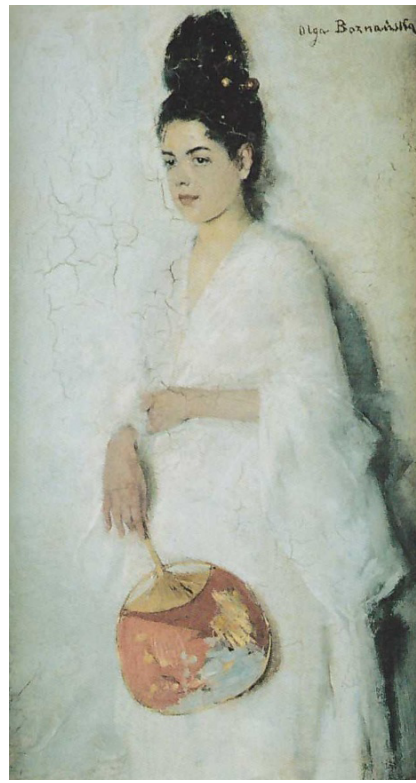




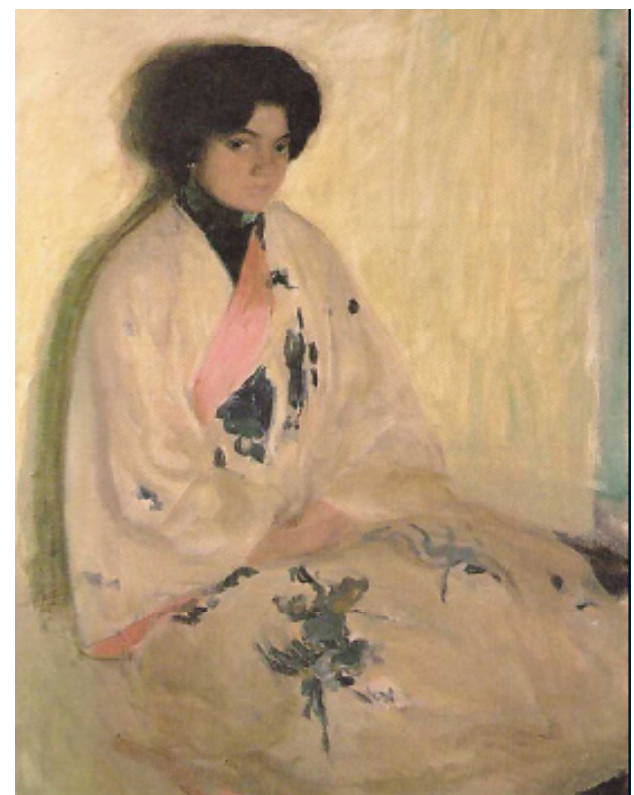

Fig. 5-5 Wojciech Weiss (18751950), Rózia in Kimono (Date unknown), Private collection

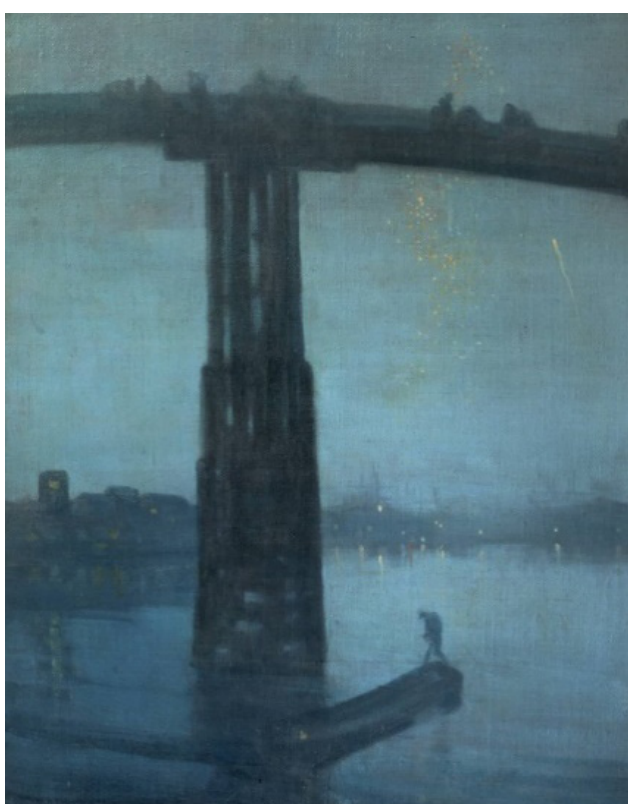

Fig. 6-2 James Abbott McNeill Whistler Fig. 6-3 Utagawa Hiroshige (1797(1834-1903), Nocturne: Blue and Gold 1858), Kyōbashi takegashi from "One - Old Battersea Bridge (ca. 1872-75), Hundred Famous Views of Edo” (1857), Tate Britain, London

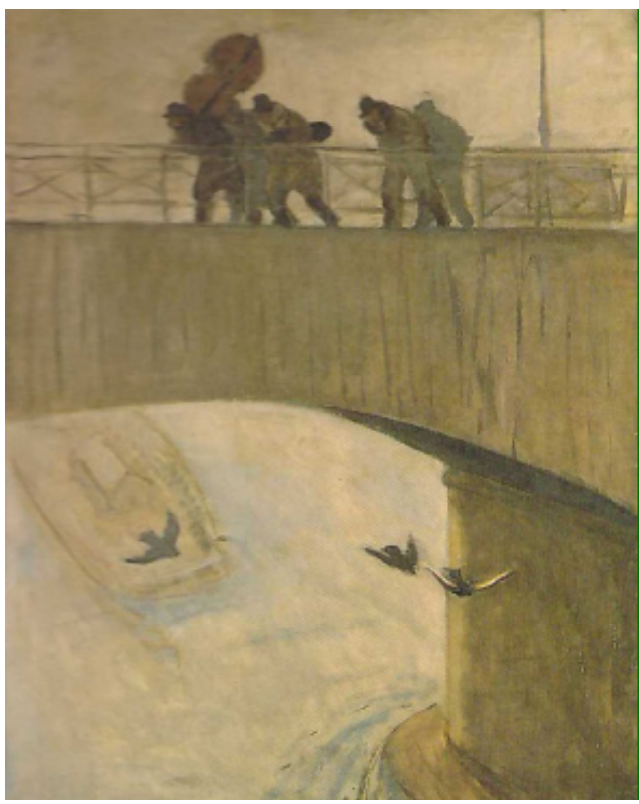

Fig. 6-1 Wojciech Weiss (1875-1950), Musicians (1904), Private collection

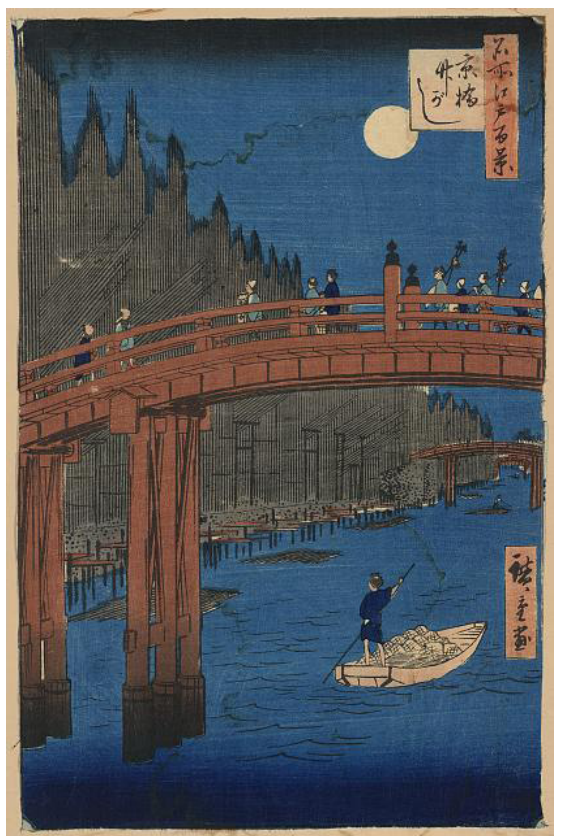

Private collection 


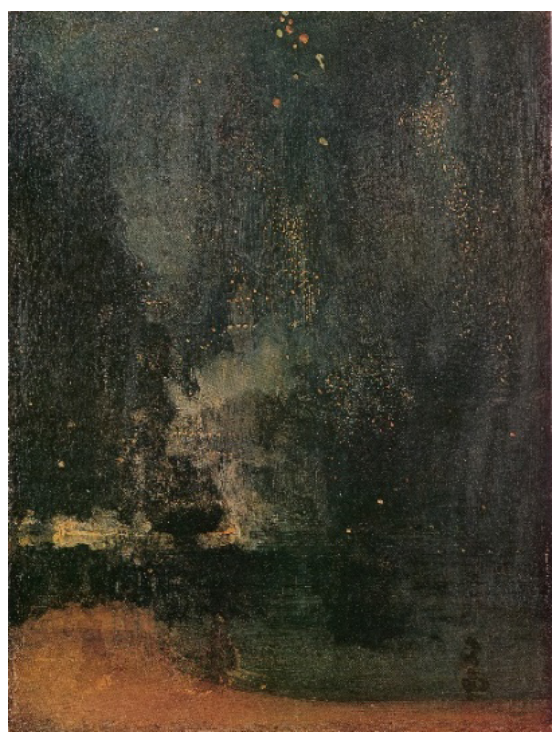

Fig. 7-1 James Abbott McNeill Whistler (1834-1903), Nocturne in Black and Gold: The Falling Rocket (1874), Detroit Institute of Arts

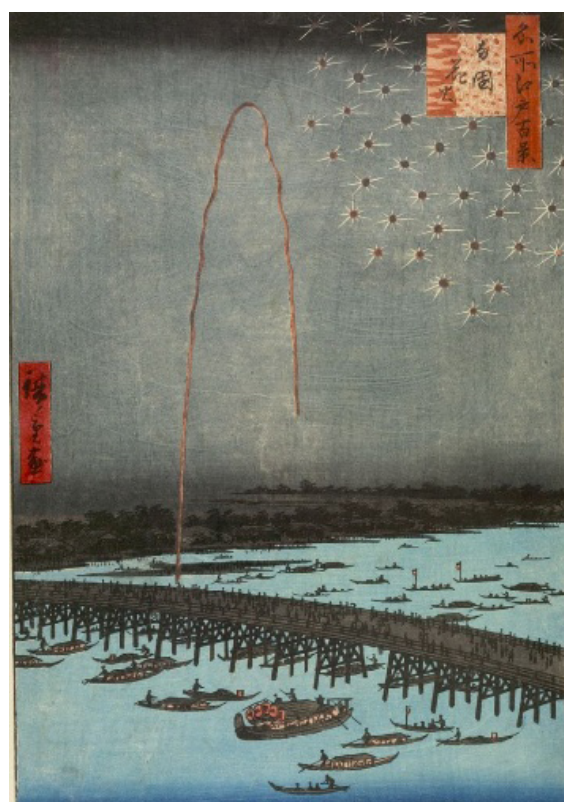

Fig. 7-2 Utagawa Hiroshige (1797-1858), Fireworks at Ryōgoku from "One Hundred Famous Views of Edo" (1856-58), Private collection

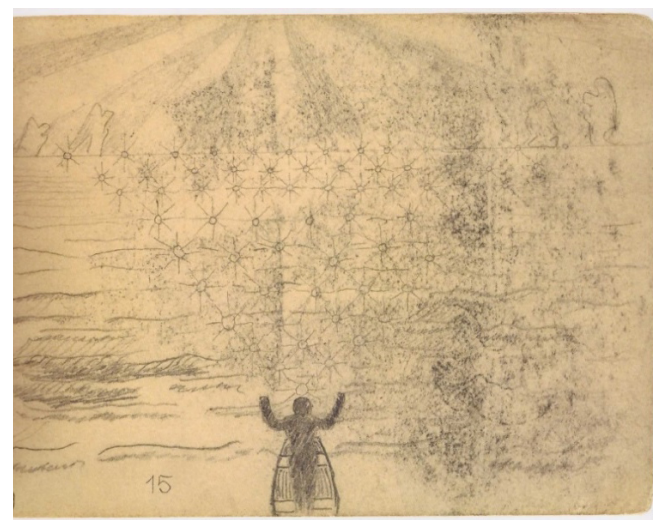

Fig. 7-3 Mikalojus Konstantinas Čiurlionis (1875-1911), Sketch for a Composition (1908), National M. K. Čiurlionis Art Museum, Kaunas

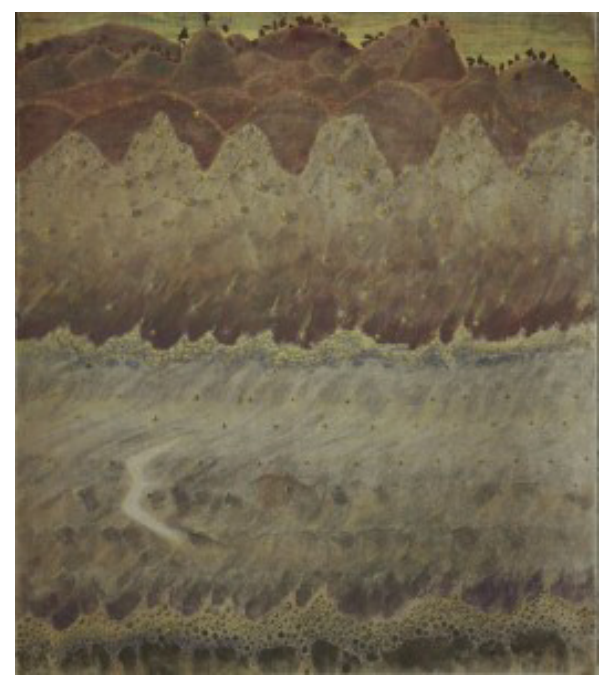

Fig. 7-4 Mikalojus Konstantinas Ciurlionis (1875-1911), Allegro from "Sonata No. 5 (Sonata of the Sea)" (1908), National M. K. Ciurlionis Art Museum, Kaunas 


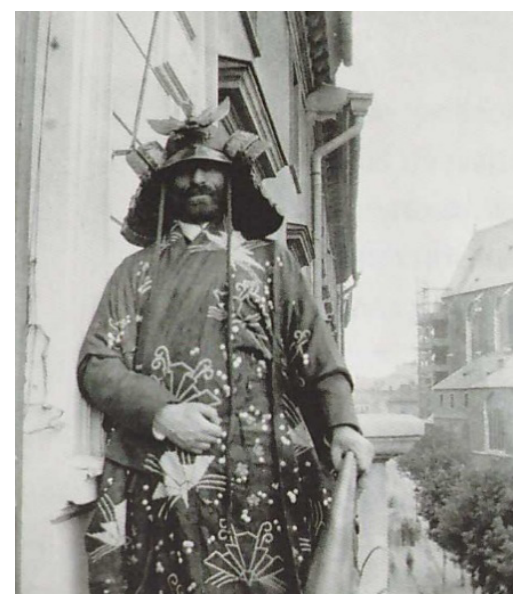

Fig. 8-1 Feliks Jasieński (1861-1929), Feliks Jasieński in Japanese helmet and kimono on the balcony of his apartment, Archival photograph, National Museum, Krakow

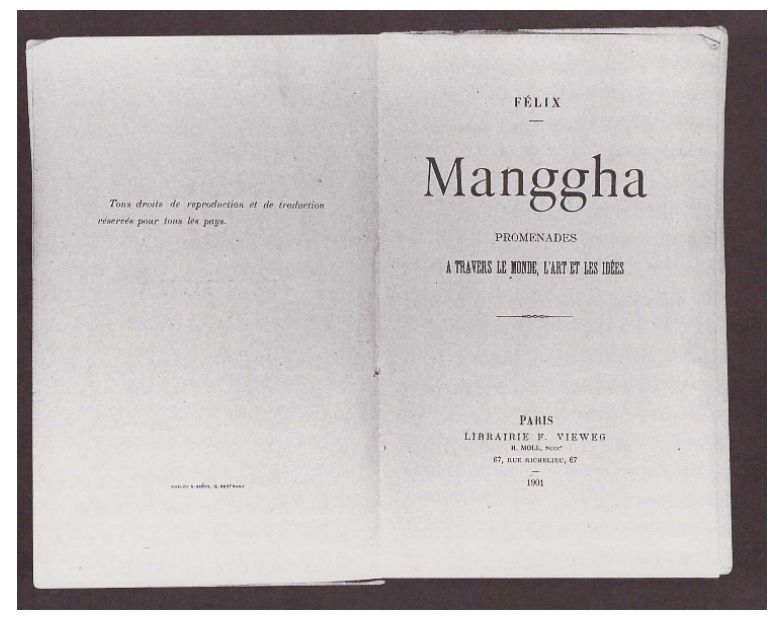

Fig. 8-2 Feliks Jasieński (18611929), Title page of "Manggha, Promenades à travers les mondes, l'art et les idées" (1901)

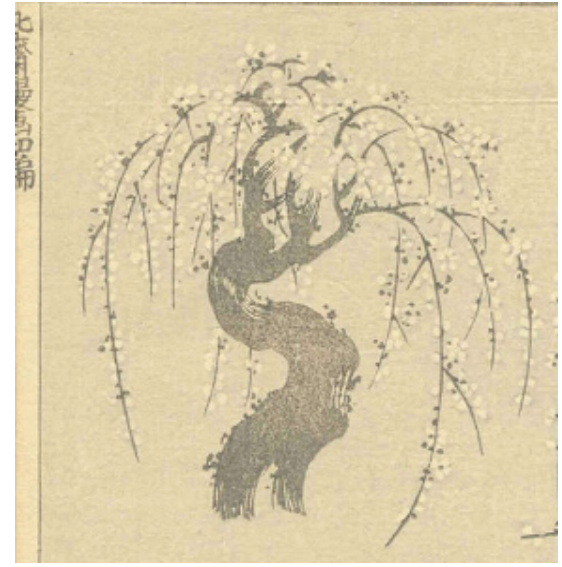

Fig. 9-1 Ferdynand Ruszczyc (1870-1936), Winter Fairytale (1904), National Museum, Krakow
Fig. 9-2 Katsushika Hokusai (1760-1849), Illustration from Hokusai Manga (published ca. 1814-78), Private collection 


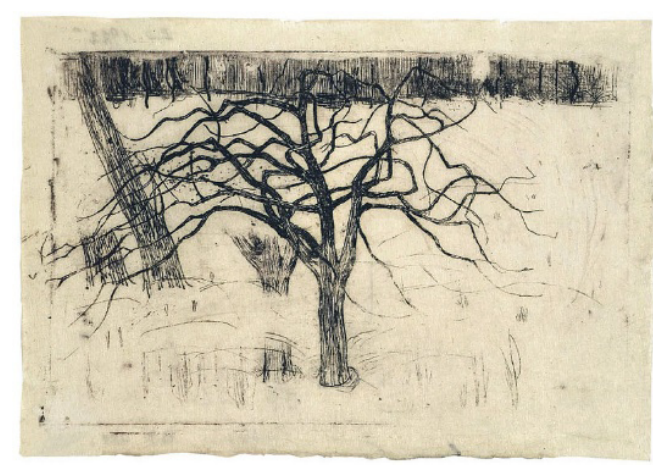

Fig. 9-3 Mikalojus Konstantinas Čiurlionis "Leafless Tree" (Fluor etching, 1905-06), National M. K. Čiurlionis Art Museum, Kaunas

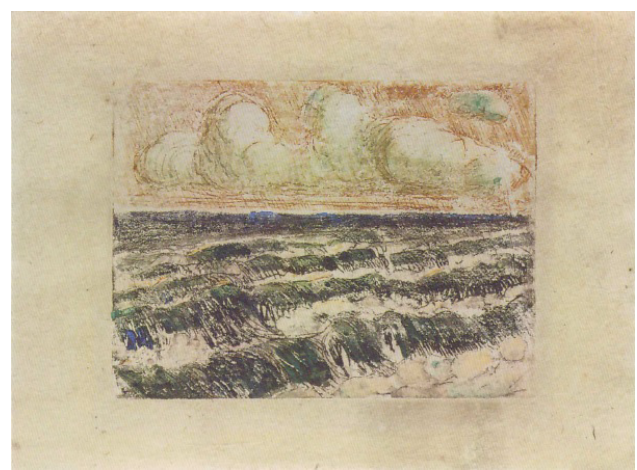

Fig. 10-1 Mikalojus Konstantinas Ciurlionis (1875-1911), The Sea (1906), National M. K. Čiurlionis Art Museum, Kaunas
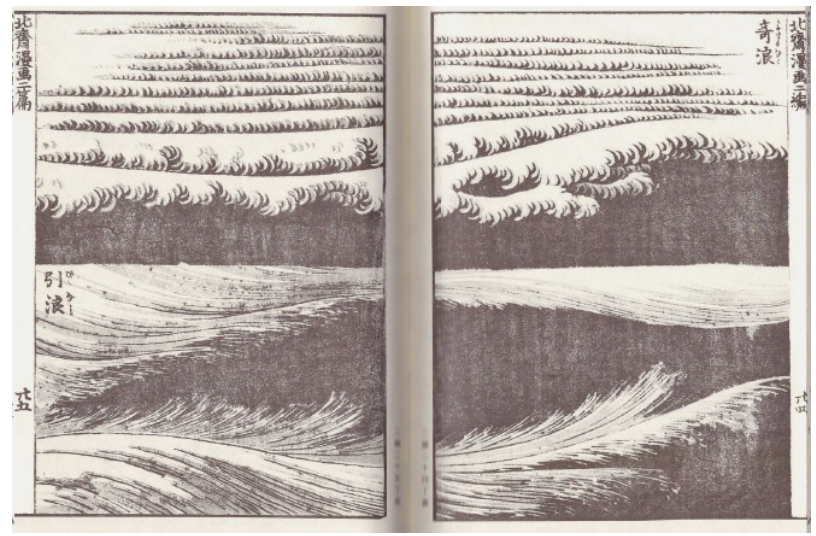

Fig. 10-2 Katsushika Hokusai (1760-1849), Illustration of waves from Hokusai Manga (published ca. 1814-78), Private collection

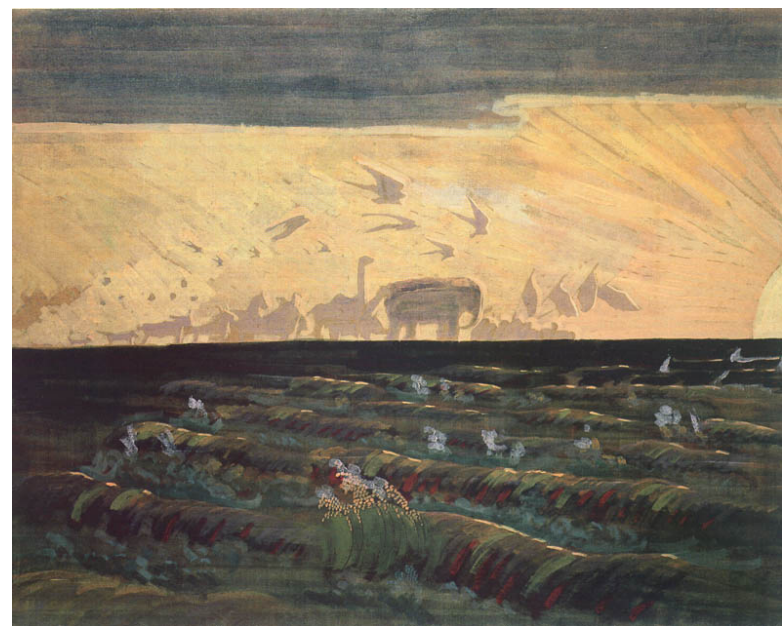

Fig. 10-3 Mikalojus Konstantinas Ciurlionis, Adoration of the Sun (1909), National M. K. Čiurlionis Art Museum, Kaunas 

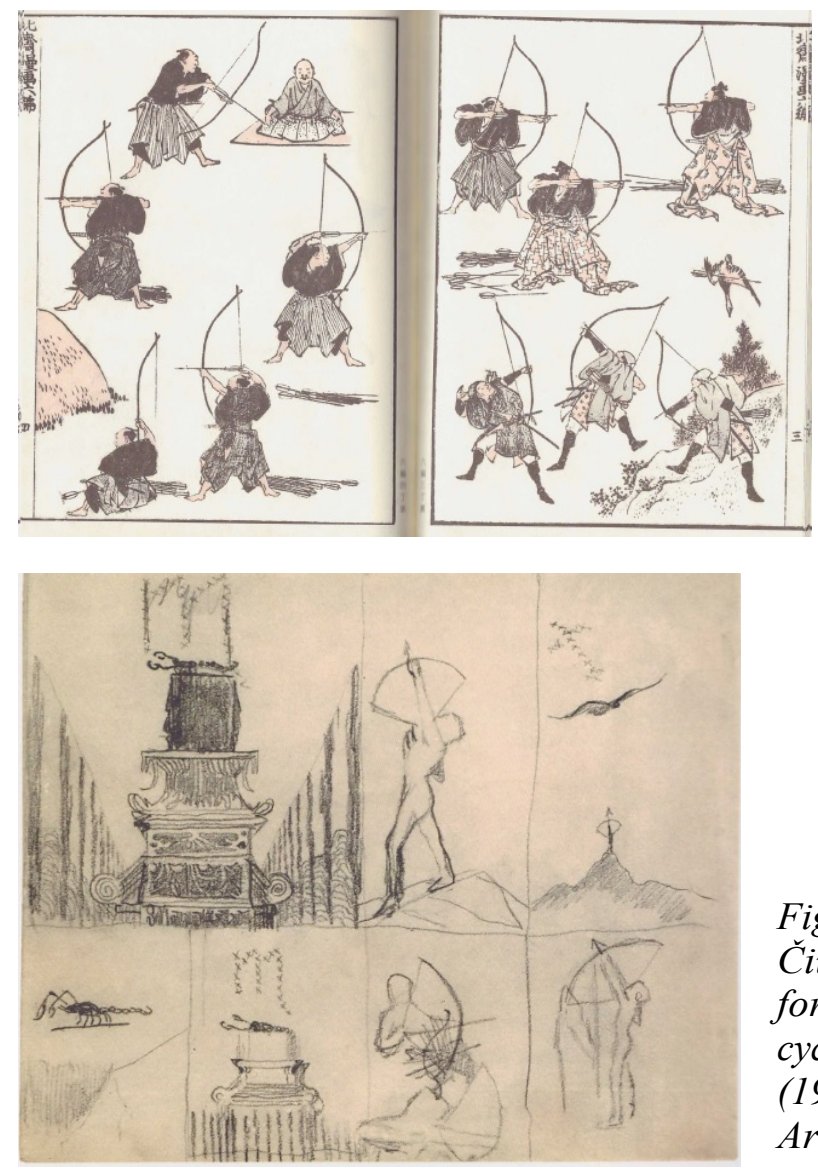

Fig. 11-1 Katsushika Hokusai (1760-1849), Illustration of archers from Hokusai Manga (published ca. 1814-78), Private collection

Fig. 11-2 Mikalojus Konstantinas Ciurlionis (1875-1911), Sketches for Sagittarius and Scorpio from cycle of 12 paintings "The Zodiac" (1906), National M. K. Čiurlionis Art Museum, Kaunas

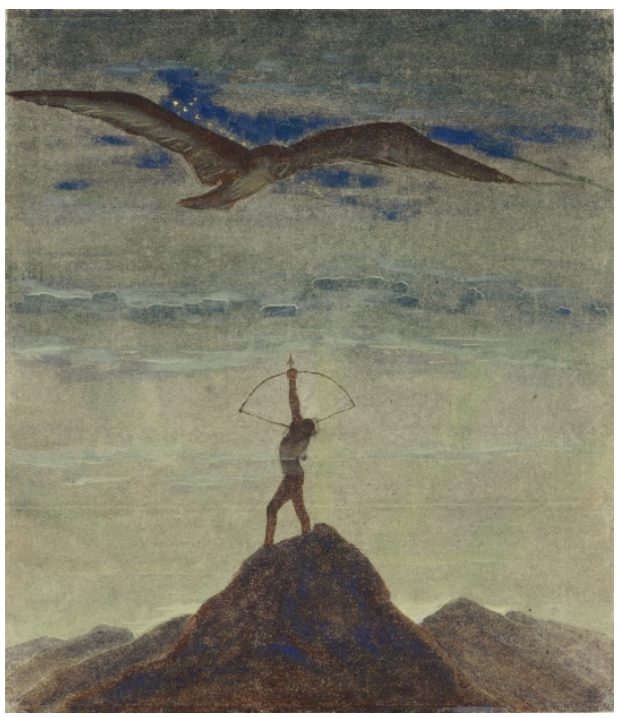

Fig. 11-3 Mikalojus Konstantinas Ciurlionis (1875-1911), The Sun is Passing the Sign of Sagittarius, from cycle of 12 paintings "The Zodiac" (1906/ 07), National M. K. Ciurlionis Art Museum, Kaunas 


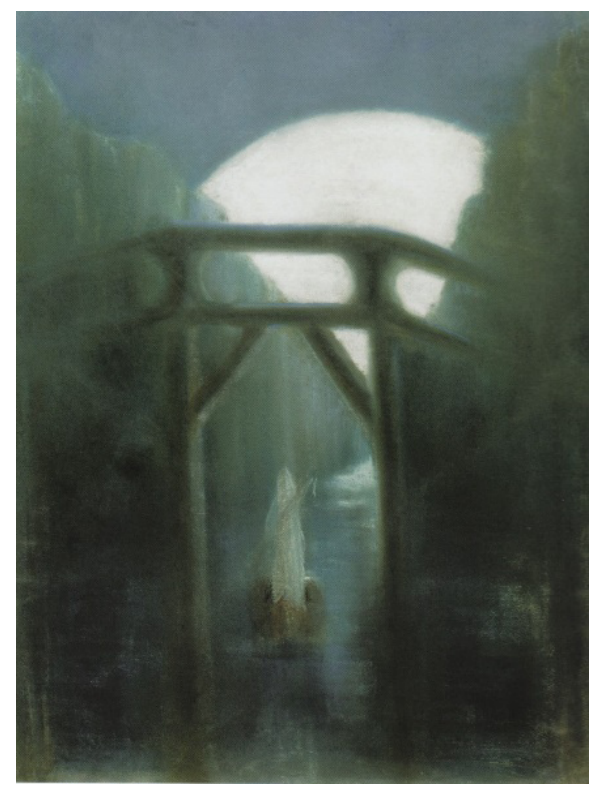

Fig. 12-1 Mikalojus Konstantinas Čiurlionis (1875-1911), Night, from cycle of 10 paintings "Fantasies" (1904/ 5), National M. K. Čiurlionis Art Museum, Kaunas

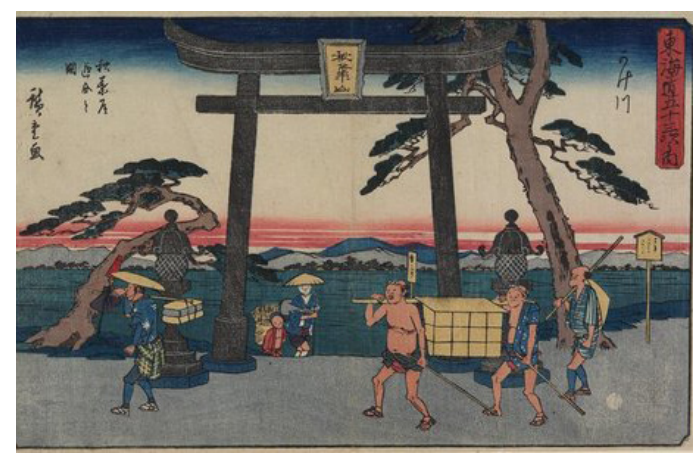

Fig. 12-2 Utagawa Hiroshige (1797-1858), The Fork of Akiba in Kakegawa (1843-47), Private collection

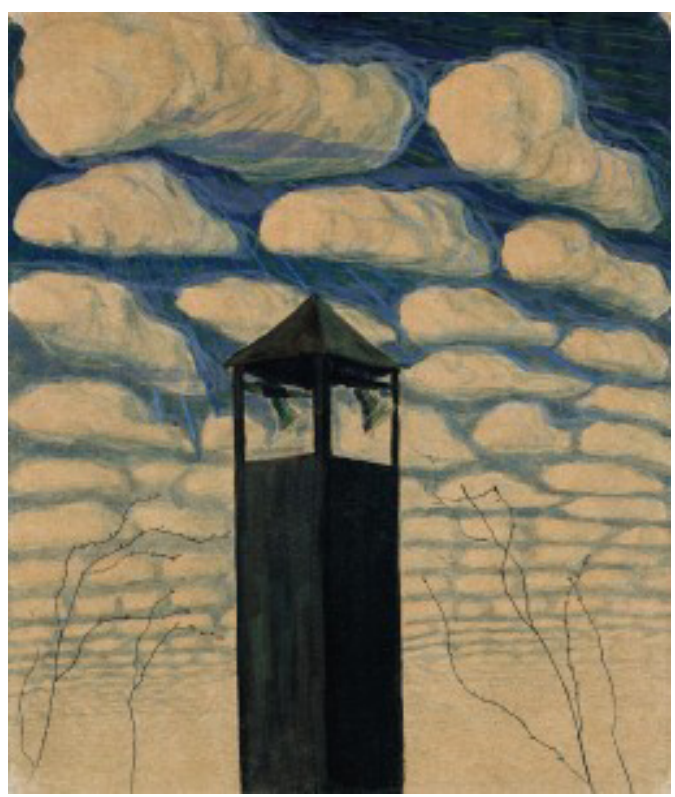

Fig. 13-1 Mikalojus Konstantinas Čiurlionis (1875-1911), Spring Motif (1907), National M. K. Ciurlionis Art Museum, Kaunas

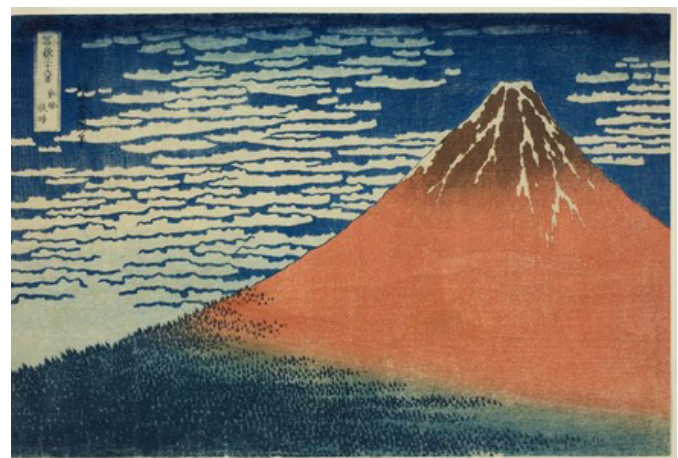

Fig. 13-2 Katsushika Hokusai (1760-1849), Mount Fuji Viewed during a Fine Wind on a Clear Morning from "Thirty-Six Views of Mount Fuji” (ca. 1830-32), Private collection 


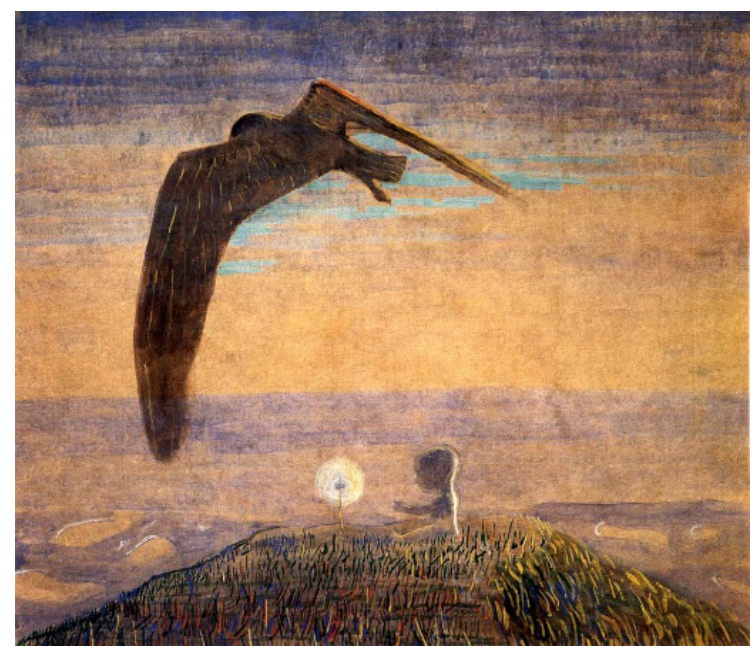

Fig. 14-1 Mikalojus Konstantinas Čiurlionis (1875-1911), Fairy Tale No. 2 from triptych "Fairy Tale" (1907), National $M$. K. Ciurlionis Art Museum, Kaunas

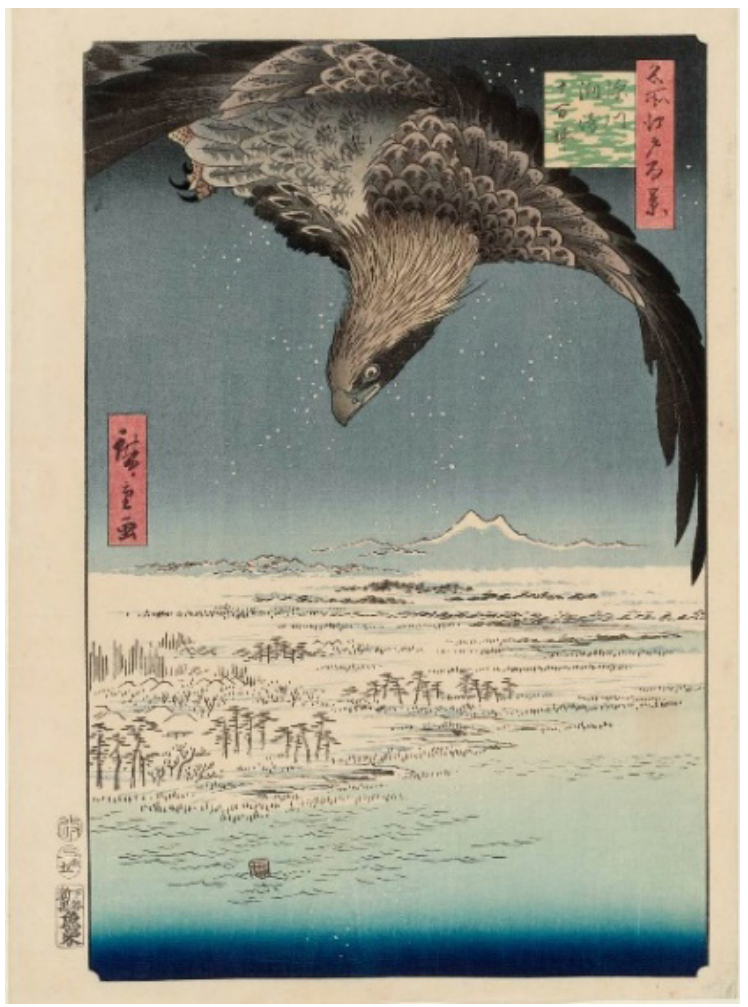

Fig. 14-2 Utagawa Hiroshige (1797-1858), Susaki and the Jümantsubo Plain near Fukagawa from "One Hundred Famous Views of Edo" (1856-58), Private collection 


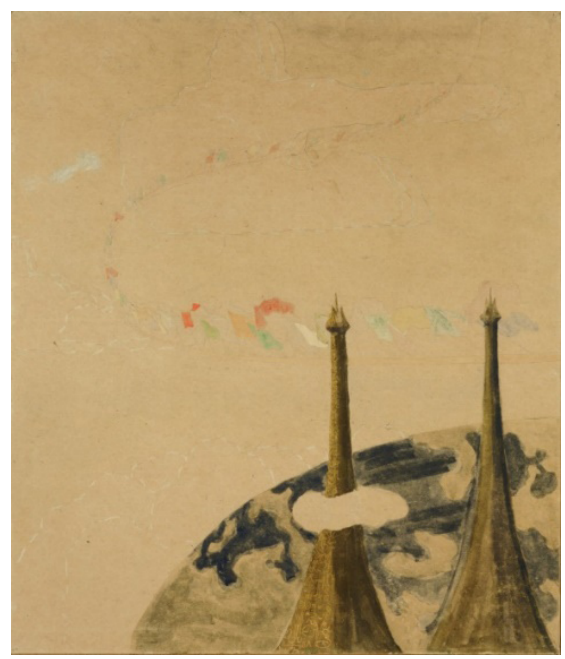

Fig. 15-1 Mikalojus Konstantinas Čiurlionis (1875-1911), Finale from "Sonata No. 2 (Sonata of the Spring)" (1907), National M. K. Ciurlionis Art Museum, Kaunas

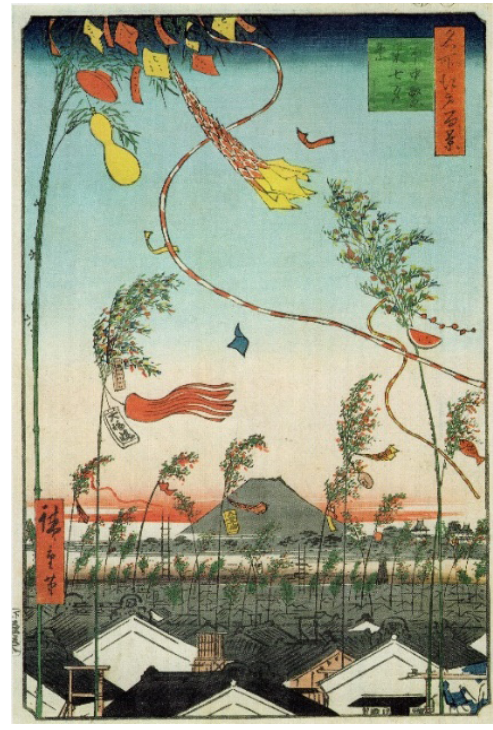

Fig. 15-2 Utagawa Hiroshige (1797-1858), The City Flourishing, the Tanabata Festival from "One Hundred Famous Views of Edo" (1856-58), Private collection 


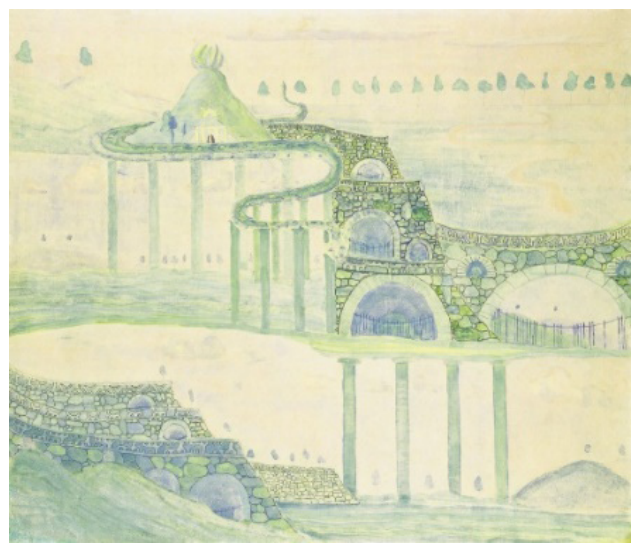

Fig. 16-1 Mikalojus Konstantinas Čiurlionis (1875-1911), Allegro from "Sonata No. 3 (Sonata of the Serpent)" (1908), National M. K. Čiurlionis Art Museum, Kaunas

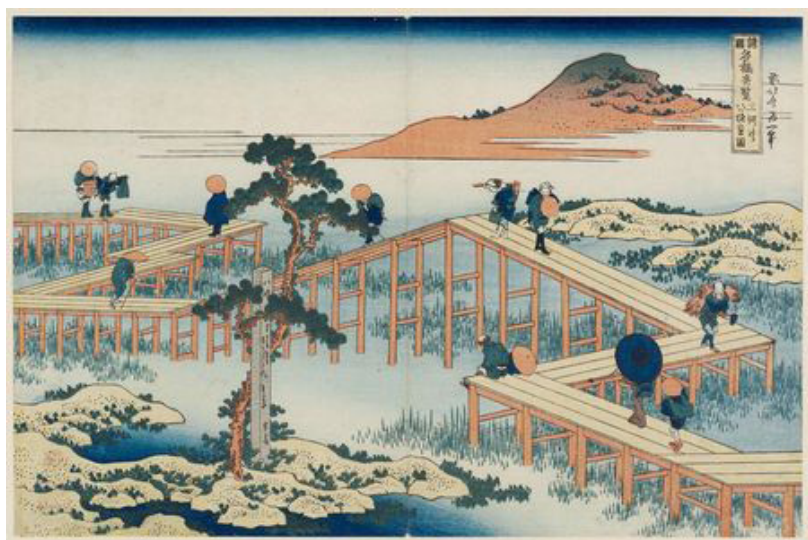

Fig. 16-2 Katsushika Hokusai (1760-1849), Old View of the Eight-part Bridge at Yatsuhashi in Mikawa Province from "Remarkable Views of Bridges in Various Provinces" (1834), Private collection

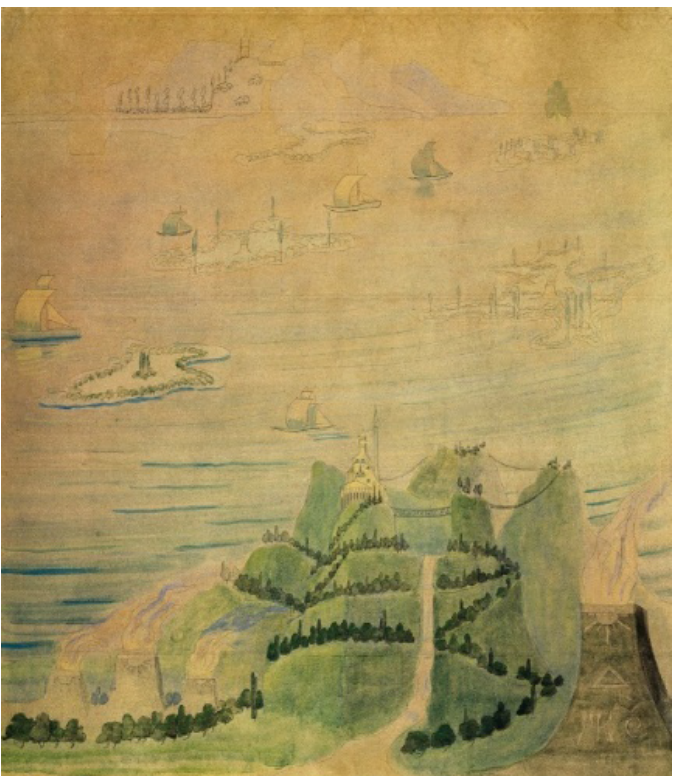

Fig. 17-1 Mikalojus Konstantinas Ciurlionis (1875-1911), Allegro from "Sonata No. 4 (Summer Sonata)" (1908), National M. K. Ciurlionis Art Museum, Kaunas

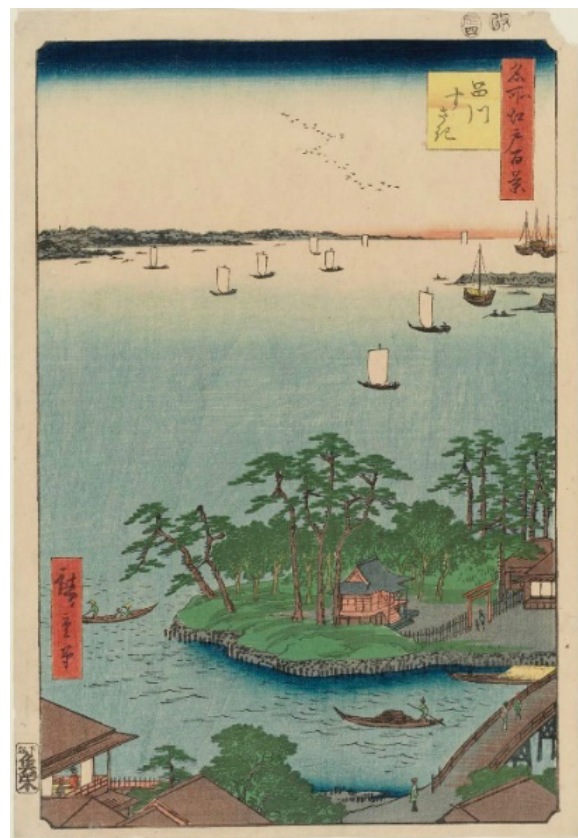

Fig. 17-2 Utagawa Hiroshige (17971858), Shinagawa Susaki from "One Hundred Famous Views of Edo" (1856-58), Private collection 

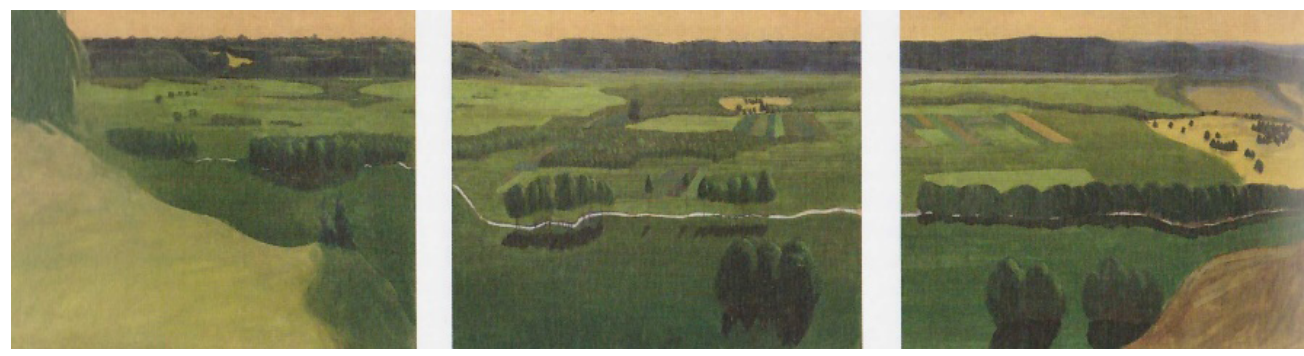

Fig. 18-1 Mikalojus Konstantinas Čiurlionis (1875-1911), Raigardas (triptych) (1907), National M. K. Čiurlionis Art Museum, Kaunas

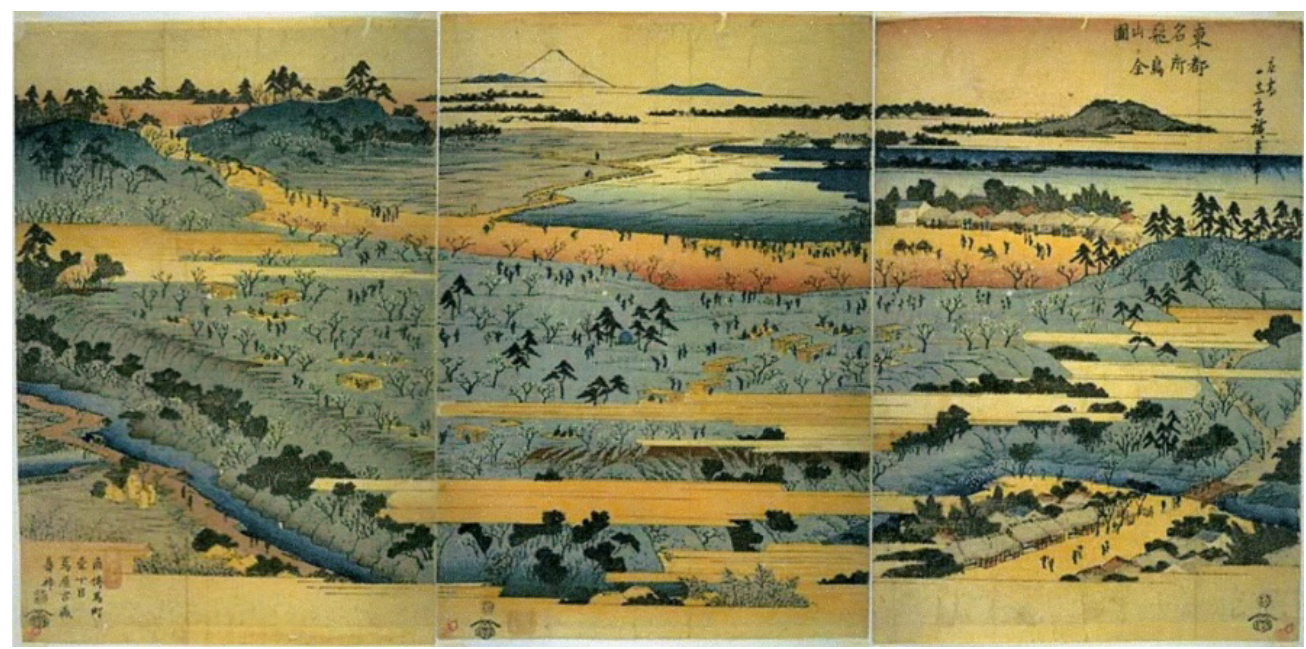

Fig. 18-2 Utagawa Hiroshige (1797-1858), Whole View of Asukayama (triptych) from "Famous Views of the Eastern Capital" (c. 1835-39), Private collection 


\section{Endnotes}

1 Exhibition title "M. K. Čiurlionis: Fantasist and Mystic of Fin-de-siècle Lithuania". Sezon Museum, Tokyo. From March $7^{\text {th }}$ to April $5^{\text {th }}$, 1992.150 works in total were exhibited including 60 paintings.

2 Christopher Newall. "Crane, Walter." Grove Art Online. Oxford Art Online. Oxford University Press, accessed September 14, 2014, http://www.oxfordartonline.com/ subscriber/article/grove/art/T020135.

3 The fact was told by Prof. Andriušytė-Žukienè directly to the author through e-mail on October 12th, 2010.

4 These resemblances have been pointed out by many scholars: Child (1889), Pennell (1911) and Ono (2003).

5 Also mentioned in Andriušytė-Žukienè (2004): 98.

6 Lithuanian scholars, Andrijauskas (2003, 2011 and 2013) and Andriušytė-Žukienè (2004) also mentioned about the influences of Japanese ukiyo-e on Čiurlionis' paintings.

7 Čiurlionis composed Variations on the Theme Sefaa Esec (VL 258) (1904) and Variations on the Theme Besacas (VL 265) (1904-05?). Both of the works adopt his friend's initials as the themes.

\section{About Author}

\section{Yumiko NUNOKAWA}

She is a graduate of Goldsmiths College, University of London with a Master of Music Degree (MMus). Currently, she is a doctoral candidate in Musicology at Kaunas University of Technology. Her articles on Serge Prokofiev appeared in Three Oranges Journal (No. 15 and 24) of the Serge Prokofiev Foundation London in 2008 and 2012. In 2008, she contributed to the publication of the Japanese edition of Prof. Vytautas Landsbergis' book Čiurlionis: Time and Content. In 2009 she wrote a concert programme for the Ibelhauptas Piano Duo's concert and contributed articles for a lecture-concert by V. Landsbergis in Tokyo. In 2011 she contributed to the publication of Čiurlionis' Piano Works (URTEXT) edited by Darius Kučinskas (Tokyo: Yamaha Music Corp.) and wrote an article on Čiurlionis' reception in Japan. Since 2010 Yumiko Nunokawa has been a regular participant in Čiurlionis themed conferences in Lithuania. Her recent interests are on Čiurlionis, Lithuanian folk song music, Synthesis of the Arts in Fin-de-Siècle Europe, and Japonisme.

nunocchi@gmail.com 